\title{
Comparison of Ovarian Function and Circulating Steroids in Estrous Cycles of Holstein Heifers and Lactating Cows
}

\author{
R. Sartori, ${ }^{1}$ J. M. Haughian, ${ }^{1}$ R. D. Shaver, ${ }^{1}$ G. J. M. Rosa, ${ }^{2}$ and M. C. Wiltbank ${ }^{1}$ \\ ${ }^{1}$ Dairy Science Department, University of Wisconsin, Madison 53706 and \\ ${ }^{2}$ Departments of Animal Science, and Fisheries \& Wildlife, \\ Michigan State University, East Lansing, 48824
}

\section{ABSTRACT}

Ovarian function was compared between nulliparous heifers ( $\mathrm{n}=29 ; 10$ to 16 mo old) and lactating Holstein cows ( $\mathrm{n}=31 ; 55.9 \pm 3.5 \mathrm{~d}$ postpartum). Follicular dynamics, corpus luteum growth, and regression, and serum steroid concentrations were evaluated through ultrasonography and daily blood sampling. Most heifers (27 of 29) but only 14 of 31 cows had typical spontaneous estrous cycles after cycles were initiated. Twelve cows had atypical cycles, and 5 became anovulatory during the study. The 12 cows with atypical estrous cycles had low serum estradiol after luteolysis and failed to ovulate the dominant follicle present at luteolysis. Heifers and cows with typical cycles were compared directly. Interovulatory intervals were similar between heifers $(22.0 \pm 0.4$ d) and cows $(22.9 \pm 0.7 \mathrm{~d})$. Those animals had estrous cycles with either 2 (15 heifers; 11 cows), 3 (9 heifers; 2 cows), or 4 follicular waves (3 heifers; 1 cow). Cows ovulated later after luteolysis than heifers (5.2 \pm 0.2 vs. 4.6 $\pm 0.1 \mathrm{~d}$, respectively), and had more multiple ovulations (17.9 vs. $1.9 \%$ ). Maximal serum estradiol concentration preceding ovulation was lower in cows than in heifers $(7.9 \pm 0.8$ vs. $11.3 \pm 0.6 \mathrm{pg} / \mathrm{mL})$ even though ovulatory follicles were larger in cows $(16.8 \pm 0.5$ vs. $14.9 \pm 0.2$ $\mathrm{mm})$. Similarly, maximal serum progesterone concentration was lower for cows ( $5.6 \pm 0.5$ vs. $7.3 \pm 0.4 \mathrm{ng} / \mathrm{mL})$, whereas maximal volume of luteal tissue was larger for cows than heifers $\left(11,120 \pm 678\right.$ vs. $\left.7303 \pm 308 \mathrm{~mm}^{3}\right)$. Thus, higher incidence of reproductive anomalies in lactating cows, such as low conception rate, ovulation failure, delayed ovulation, and multiple ovulations, may be due to lower circulating steroid concentrations in spite of larger ovulatory follicles and luteal structures.

(Key words: estrous cycle, ovary, estradiol, progesterone)

Received December 17, 2002.

Accepted August 4, 2003.

Corresponding author: M. C. Wiltbank; e-mail: wiltbank@calshp. cals.wisc.edu.
Abbreviation key: $\mathbf{C L}=$ corpus luteum or corpora lutea, $\mathbf{C R}=$ conception rate, $\mathbf{E}_{\mathbf{2}}=$ estradiol, $\mathbf{P}_{\mathbf{4}}=$ progesterone.

\section{INTRODUCTION}

Dairy cow fertility has become a major problem, as reported by recent studies, that demonstrate very low conception rates $(\mathbf{C R})$ in high-producing cows (Royal et al., 2000; Washburn et al., 2002). Moreover, high incidences of reproductive abnormalities such as cystic ovarian disease (Garverick, 1997; López-Gatius et al., 2002; Wiltbank et al., 2002), delayed ovulation (Lamming and Darwash, 1998; Royal et al., 2000; Nakao et al., 1992), reduced length and/or intensity of behavioral estrus (Nebel et al., 1997; Dransfield et al., 1998), or twinning (Nielen et al., 1989; Kinsel et al., 1998) have been observed, particularly in high-producing cows. In contrast, nulliparous heifers have few reproductive abnormalities, and CR has been consistently above 50 to 60\% (Spalding et al., 1975; Ahmad et al., 1996; Pursley et al., 1997).

Although studies have characterized reproductive traits in dairy cows and heifers, no study has simultaneously compared characteristics of estrous cycles in heifers and cows. Therefore, the objective of this study was to describe differences between cows and heifers in the dynamics of ovarian morphology and reproductive hormones during the estrous cycle as one step in examining reasons for poor fertility in high-producing, lactating dairy cows. We hypothesized that mature CL would be larger in lactating cows despite having serum progesterone $\left(\mathbf{P}_{4}\right)$ concentrations similar to that of heifers. Further, we hypothesized that following luteolysis, lactating cows require more time to reach preovulatory estradiol $\left(\mathbf{E}_{2}\right)$ concentrations similar to that of heifers, thereby delaying estrus and resulting in ovulation of larger follicles.

\section{MATERIALS AND METHODS}

Selection of animals. From May 24 to July 22 of 1999, 31 lactating Holstein cows (7 primiparous and 24 multiparous; $55.9 \pm 3.5$ d postpartum [mean \pm SEM; 
range 20 to $91 \mathrm{~d}$ ]; daily milk production of $45.7 \pm 1.3 \mathrm{~kg}$ [range 31.0 to $62.0 \mathrm{~kg}$ ]; $4.0 \pm 0.3 \mathrm{yr}$ old [range 2 to $9 \mathrm{yr}$ ]), and 29 nulliparous Holstein heifers (10 to 16 mo old) were studied. Cows and heifers had their ovaries scanned by daily ultrasound (Aloka $500-\mathrm{V}$ with a 7.5 $\mathrm{MHz}$ linear-array transducer; Corometrics Medical Systems Inc., Wallingford, CT) for follicular and luteal structures. Females were classified as anovulatory if they did not have a CL during the first 11-d period of ultrasound evaluation ( $\mathrm{n}=13$ lactating cows and 0 heifers). Anovulatory cows were treated with an i.m. injection of $\mathrm{GnRH}$ (100 $\mu \mathrm{g}$ of Cystorelin; Merial Limited, Iselin, NJ). Cows that failed to ovulate to this first injection $(\mathrm{n}=3)$ were treated with $\mathrm{GnRH}$ again $7 \mathrm{~d}$ later and ovulated. After ovulation to $\mathrm{GnRH}, 8$ previously anovulatory cows completed 2 entire cycles, but 5 other cows redeveloped an anovulatory condition and were removed from the study. Animals with CL present by the first $11 \mathrm{~d}$ of ultrasound evaluation ( $\mathrm{n}=18$ cows and 29 heifers) were not treated with any hormones and were allowed to spontaneously ovulate. Average days postpartum at the first spontaneous ovulation after the start of ultrasound evaluation were similar $(P=0.73)$ between the 18 initially cycling cows $(80.6 \pm 4.9 \mathrm{~d})$ and the 8 cows with $\mathrm{GnRH}$-induced ovulation and subsequent spontaneous ovulation (77.8 $\pm 5.6 \mathrm{~d}$ ). One heifer did not ovulate after luteolysis and became cystic as described in Wiltbank et al. (2002) and was removed from the study. Upon detection of the second spontaneous ovulation, cows and heifers were categorized as having either a typical or an atypical cycle. Typical cycles were estrous cycles that started and ended with natural (not induced) ovulation of the follicle(s) that had emerged ( $\geq 4 \mathrm{~mm}$ diameter) at or before the day of luteolysis. The day of luteolysis was defined as the day before serum $\mathrm{P}_{4}$ declined to less than $50 \%$ of the average for the four maximum $\mathrm{P}_{4}$ concentrations in the cycle. Additionally, serum $\mathrm{P}_{4}$ must have declined again to less than $25 \%$ of the 4 maximum average $\mathrm{P}_{4}$ concentrations the following day.

Animal handling. Cows were housed in a stanchion barn at the Dairy Cattle Research Center in Madison. Heifers were housed on dirt lots with an indoor feeding area containing headlocks at the Arlington research station. Cows were milked twice daily and fed a TMR that consisted of corn silage and alfalfa silage as forage and corn-soybean meal based concentrate. The TMR contained $18.0 \% \mathrm{CP}$ and $1.65 \mathrm{Mcal} / \mathrm{kg}$ of $\mathrm{NE}_{\mathrm{L}}$ (percentage of DM). Heifers were fed a TMR consisting of $70 \%$ alfalfa silage and $30 \%$ corn silage $(16.8 \% \mathrm{CP}$ and $1.36 \mathrm{Mcal} / \mathrm{kg}$ of $\mathrm{NE}_{\mathrm{L}}$ ). Both groups had free access to water. Milk yields from cows were collected daily and BCS was evaluated at 30-d intervals. Cows and heifers had a BCS (scale from 1 to 5 ) of $3.2 \pm 0.1$ and $3.7 \pm 0.1$, respectively, at the beginning of the experiment. Cows, but not heifers, received $500 \mathrm{mg}$ (s.c.) of recombinant bST (Posilac; Monsanto Co., St. Louis, MO) at 12-d intervals starting on d 11 of the experiment, independent of stage of lactation. Use of rbST was to match requirements for a simultaneous production trial in the herd. Rectal temperatures were measured in cows at the end of estrous cycles.

Reproductive management. Cows were observed for signs of estrus at 0700 and $1900 \mathrm{~h}$ for 20 min each. In addition, each cow was fitted with a pressure-activated heat mount detector (Kamar; Kamar Inc., Steamboat Springs, CO) that was checked twice daily after milking. For heifers, the only criterion used for determination of estrous behavior was the presence of an activated Kamar that was checked once daily (0900 h). Ultrasound measurements of follicles and CL were used to calculate average diameters (average of length $[\mathrm{L}]$ and width [W]) and volume (V). Volume was calculated with the formula $\mathrm{V}=4 / 3 \times \pi \times \mathrm{R}^{3}$ using a radius $(\mathrm{R})$ calculated by the formula $R=(L / 2+W / 2) / 2$. For a CL with a fluidfilled cavity, the volume of the cavity was calculated and subtracted from the total volume of the CL.

Hormonal assays. Daily blood samples were collected by coccygeal venipuncture from all females beginning on the day of first spontaneous ovulation, or $1 \mathrm{~d}$ before the first $\mathrm{GnRH}$ treatment in anovulatory cows. Serum samples were stored at $-20^{\circ} \mathrm{C}$ until assayed. Initially, only sera from cows and heifers with typical cycles were analyzed for steroid concentrations. For analysis of $\mathrm{P}_{4}$, serum was evaluated using double extraction with petroleum ether and subsequent ELISA as previously reported (Rasmussen et al., 1996). For analysis of $\mathrm{E}_{2}$, samples were extracted twice with diethyl ether and serum concentrations of $\mathrm{E}_{2}$ were evaluated by radioimmunossay as previously reported (Kulick et al., 1999). The intraassay CV was $8.9 \%$ for $\mathrm{P}_{4}$ and $3.3 \%$ for $\mathrm{E}_{2}$. Because initially some of the samples from cows with atypical cycles were not analyzed, in order to validly compare cows with typical vs. atypical cycles, serum samples from all cows were analyzed (atypical cows) or reanalyzed (typical cows) simultaneously. For analysis of $\mathrm{E}_{2}$, the same technique of radioimmunoassay described above was used. Serum $\mathrm{P}_{4}$ concentration was, however, evaluated from unextracted sera using an antibodycoated-tube radioimmunoassay kit (Diagnostic Products Corporation, Los Angeles, CA). The intraassay CV was $3.4 \%$ for $\mathrm{P}_{4}$ and $14.0 \%$ for $\mathrm{E}_{2}$.

\section{Statistical Analyses}

For comparisons between groups, the 2 -sample $t$-test was used for continuous traits, such as milk yield, rectal temperature, size of follicles, or hormone concentrations. The chi-square methodology was used for comparing binomial variables, such as ovulation rate, or incidence of 
codominant follicles. The Yates correction for continuity was considered in all analyses, and the Fisher exact test was used whenever the cell frequencies were small and the chi-square test was not adequate (Zar, 1996). Oneway ANOVA models were used to compare heifers with 3 follicular waves, heifers with 2 waves, and cows with 2 waves. Whenever the results of the $\mathrm{F}$ tests were significant, the analyses were complemented with multiple comparisons of means using the SNK procedure. The analysis of variables measured repeatedly within animal, such as follicular and luteal development, or serum steroid concentrations during the estrous cycle, was performed by using a first-order autoregressive model for repeated measurements (Verbeke and Molenberghs, 1996). That analysis included fixed effects of experimental groups, times, and their interaction, as well as the random effect of animal. The analyses were performed using the MIXED procedure and the REPEATED command of SAS (Littell et al., 1996). All the conclusions were set considering a $5 \%$ level of significance.

\section{RESULTS AND DISCUSSION}

Profiles of ovarian function in individual heifers and lactating cows. The overall aim of this study was to compare ovarian function in lactating cows vs. nulliparous heifers. However, the variety in profiles of individual animals had to be addressed in order to perform a valid analysis of the data. Figures 1, 2, and 3 attempt to represent some of the variety in profiles that were observed in individual animals. Atypical interovulatory patterns, particularly in lactating cows, made necessary that a definition be adopted of typical vs. atypical based on whether the animal ovulated the follicle present at luteolysis. Twenty-seven of 29 heifers in this study were classified as having typical cycles. Of the 2 abnormal individuals, one heifer became cystic (Wiltbank et al., 2002) and the other heifer failed to ovulate the future dominant follicle present on the ovary at luteolysis and was not used in subsequent analyses of typical estrous cycles. That heifer did start a new follicular wave $1 \mathrm{~d}$ after luteolysis and ovulated $6 \mathrm{~d}$ after luteolysis similar to one heifer in the study by Quirk et al. (1986). Figure 1 depicts the profiles of 3 heifers that were classified as typical and are somewhat representative of the different profiles observed in individual heifers. Similar to the descriptions in the literature, heifers had $2(\mathrm{n}=15$; Figure 1A), $3(\mathrm{n}=9$; Figure 1B), or $4(\mathrm{n}=3$; Figure $1 \mathrm{C})$ follicular waves during the interovulatory period. Some investigators have reported that Holstein heifers primarily had 2 follicular waves (Ginther et al., 1989; Knopf et al., 1989; Ko et al., 1991; Wilson et al., 1998a; Inbar et al., 2001; Kulick et al., 2001), whereas Sirois and Fortune (1988) reported primarily 3 follicular waves dur-
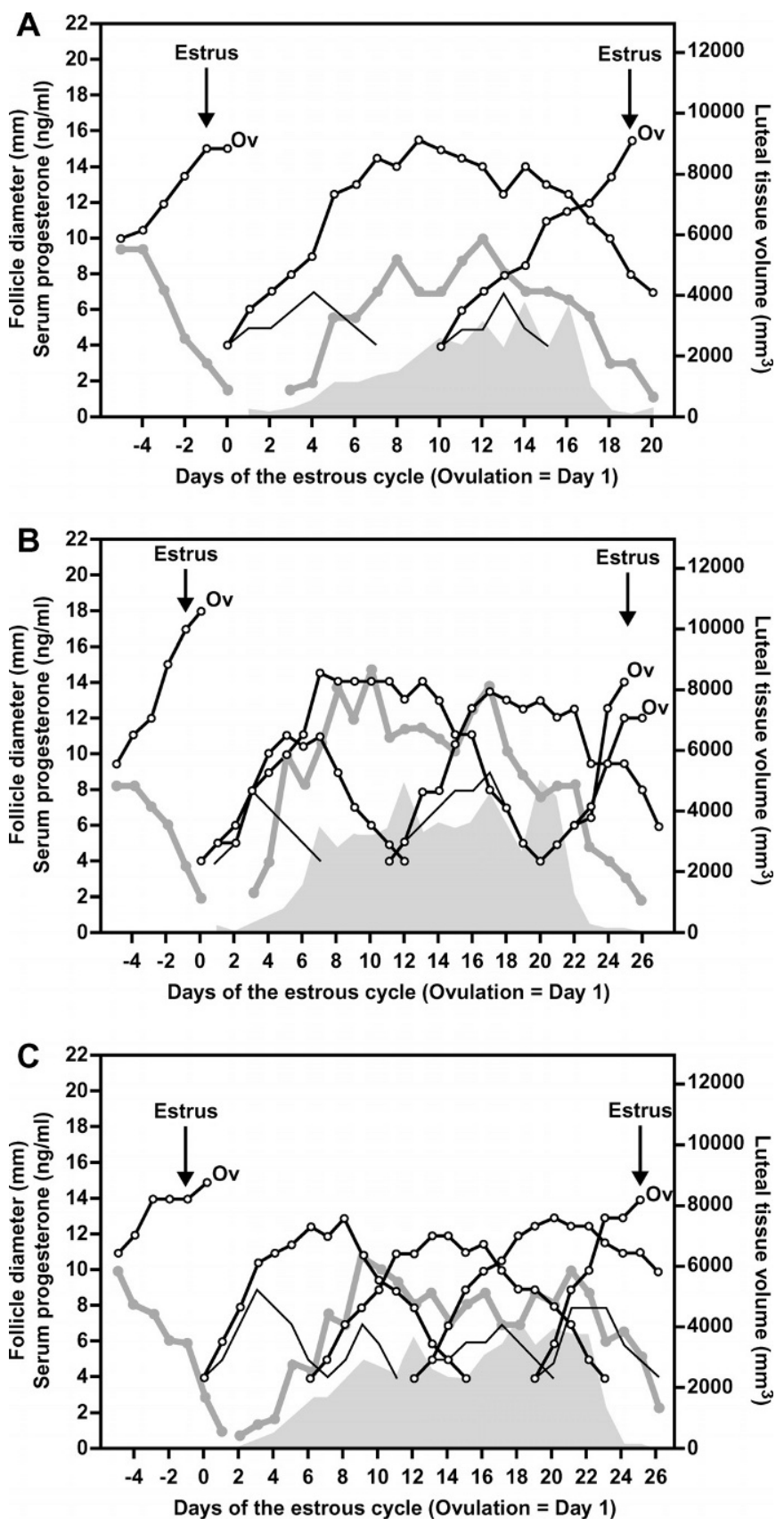

Figure 1. Patterns of follicular (solid black lines: dominant follicles $=$ thick lines with open circles; subordinate follicles $=$ thin lines) and luteal development (gray lines with solid circles), and serum progesterone concentration (gray area) of nulliparous heifers with typical cycles. A. Heifer with 2 follicular waves and single ovulation (Ov). B. Heifer with 3 follicular waves and double ovulation. C. Heifer with 4 follicular waves and single ovulation. Estrus was detected before both the first and second ovulation in all 3 heifers.

ing the estrous cycle of Holstein heifers, as did Savio et al. (1988) and Gong et al. (1993) for beef (Hereford x Holstein) heifers. Sirois and Fortune (1988) and Inbar 

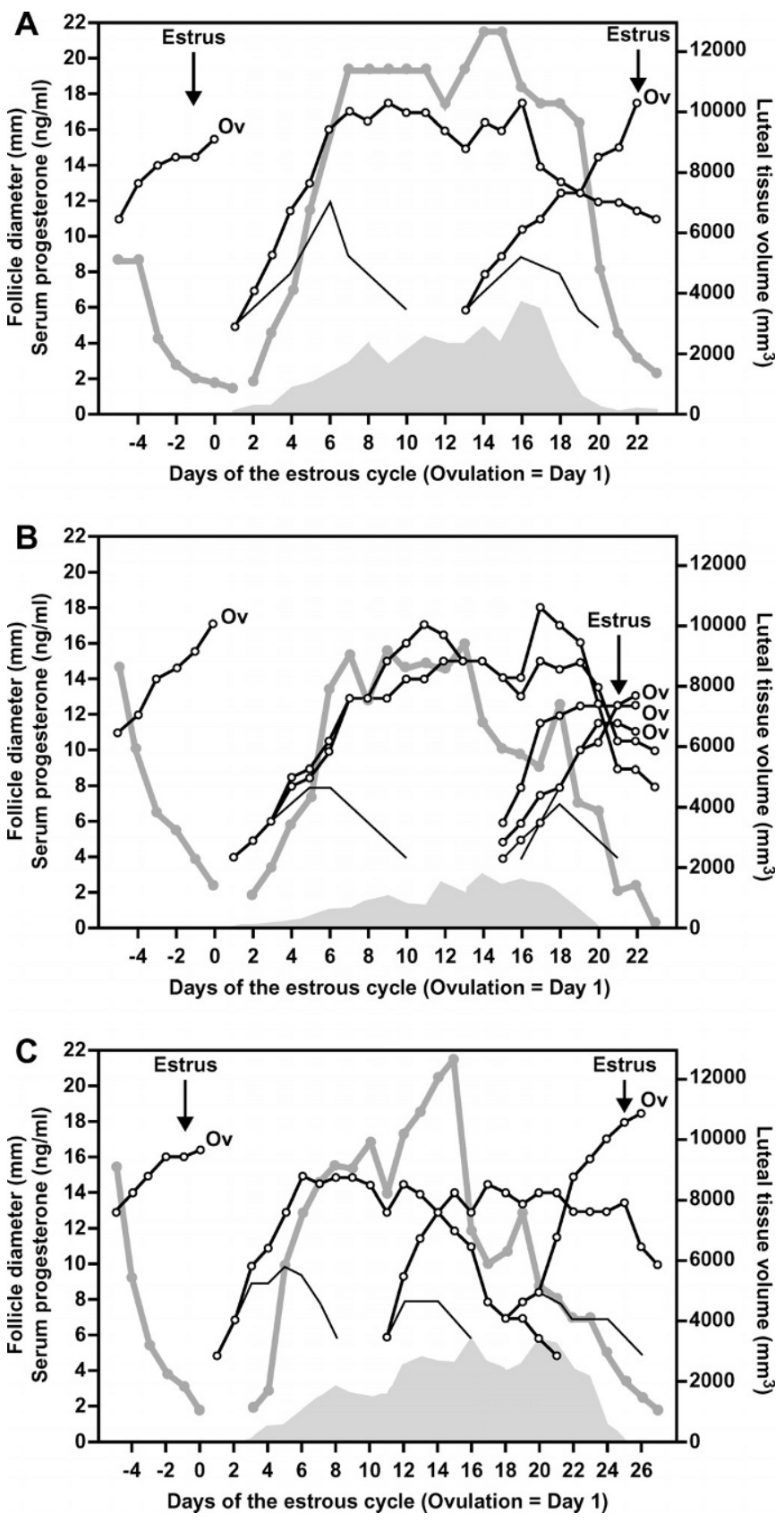

Figure 2. Patterns of follicular (black lines: dominant follicles = thick lines with open circles; subordinate follicles = thin lines) and luteal development (gray lines with solid circles), and serum progesterone concentration (gray area) of lactating cows with typical cycles. A. Cow with 2 follicular waves and single ovulation (Ov). B. Cow with 2 follicular waves and triple ovulation. C. Cow with 3 follicular waves and single ovulation. Estrus was detected before 5 of 6 ovulations.

et al. (2001) each reported one heifer with 4 follicular waves.

Codominant follicles resulting in double ovulation were observed in only one heifer (Figure 1B). Other stud-
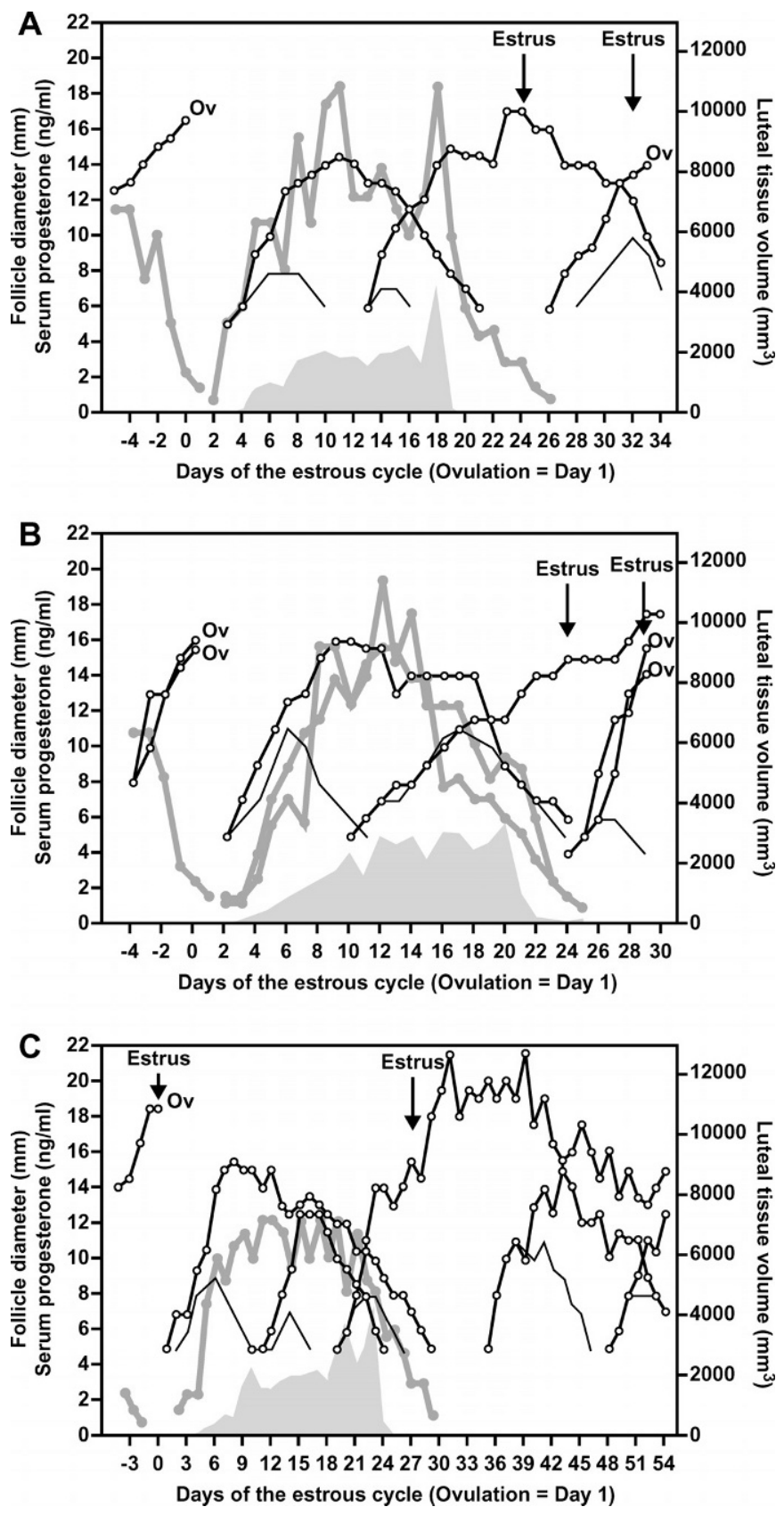

Figure 3. Patterns of follicular (black lines: dominant follicles = thick lines with open circles; subordinate follicles $=$ thin lines) and luteal development (gray lines with solid circles), and serum progesterone concentration (gray area) of lactating cows with atypical cycles. A. Cow with 2 follicular waves until luteolysis and single ovulation (Ov) of the follicle that emerged after luteolysis. Estrus was not detected before the first ovulation, but was detected after luteolysis despite lack of ovulation, and also before the next ovulation. B. Cow with 2 follicular waves until luteolysis and ovulation of 2 follicles that emerged after luteolysis. Estrus was not detected before the first ovulation (double), but was detected after luteolysis despite lack of ovulation, and also before the next ovulation (double). C. Cow with 3 follicular waves until luteolysis and absence of ovulation for $>25 \mathrm{~d}$ after luteolysis. Estrus was detected before the first ovulation and again was detected after luteolysis despite ovulation failure. 
ies of follicular waves in heifers did not report codominance or double ovulation (Quirk et al., 1986; Sirois and Fortune, 1988; Ginther et al., 1989; Ko et al., 1991); however, Kulick et al. (2001) observed an incidence of codominance of 35,4 , and $10 \%$ during the first, second, and third follicular waves, respectively, in older, large heifers.

Follicular profiles of individual cows differed from the profiles for heifers. Of 26 cows that were ovulatory and selected for further study, only 14 cows had a profile that would be classified as typical (examples in Figure 2). Similar to other reports in lactating dairy cows (Taylor and Rajamahendran, 1991; Wilson et al., 1998b; Roth et al., 2000; Inbar et al., 2001; Townson et al., 2002), the 2 -wave pattern was most common in our study ( $\mathrm{n}=$ 11; Figure $2 \mathrm{~A}$ and $\mathrm{B}$ ), but there were also cows that had $3(\mathrm{n}=2$; Figure $2 \mathrm{C})$ and 4 follicular waves $(\mathrm{n}=1)$. In contrast, a predominance of 3 follicular waves in lactating dairy cows has been reported (Savio et al., 1990a; Pursley et al., 1993).

Five $(35.7 \%)$ and three $(21.4 \%)$ cows had more than one dominant follicle during the first and last follicular waves, respectively. The cow in Figure 2B had codominant follicles during both first and second follicular waves and ovulated 3 follicles from the second wave. High incidences (10 to 39\%) of multiple ovulations in high-producing dairy cows have been described by several authors (Fricke and Wiltbank, 1999; Santos et al., 2000; Vasconcelos et al., 2001). In cows that ovulated multiple follicles, all ovulatory follicles emerged in the same follicular wave.

In addition to five cows that were anovulatory and not included for further study, one distinct and interesting subgroup were those cows that became temporarily (11 cows; examples in Figure 3A and B), or permanently ( $>30 \mathrm{~d}$ ) anovulatory (one cow; Figure $3 \mathrm{C}$ ), after luteolysis. Therefore, 12 cows that had previously had a normal luteal phase were considered to have an atypical cycle. The abnormality occurred during the first spontaneous ovulation for 5 cows, and at the expected time of the second spontaneous ovulation for the other 7 cows. Similar occurrences were defined as "prolonged inter-luteal interval," or "delayed ovulation Type II" (Nakao et al., 1992; Lamming and Darwash, 1998). Other authors (Walker et al., 1996; Royal et al., 2000) have also reported these observations, although neither profiles of follicular and luteal development nor serum steroid concentrations were reported. In our study, the atypical cows had $1(n=1), 2(n=10$; Figures $3 A$ and $3 B)$, or $3(n=1$; Figure 3C) follicular waves before CL regression. However, after luteolysis, ovulation did not occur despite expression of estrus. A new wave emerged, another estrus was observed after a delay of a few days and then, 11 of 12 cows ovulated.
Lactating cows with typical vs. atypical patterns. The high incidence of cows with atypical patterns was unexpected but offered a unique opportunity to study the hormonal and ovarian profiles that characterize this condition. Lactating cows were classified as either typical $(n=14)$ or atypical $(n=12)$ based on whether the dominant or future dominant follicle that was present at the time of luteolysis subsequently ovulated (see Figures 2 and 3). Ovarian function was contrasted for cows classified as typical or atypical during comparable periods. Three cows with atypical cycles did not have blood samples collected during this period, and, therefore, data from those cows are not presented.

It was expected that cows with atypical cycles $(n=8$ with data) would have longer interovulatory intervals compared with typical cows $(n=14)$ as was observed $(29.3 \pm 1.1$ vs. $22.9 \pm 0.7 \mathrm{~d})$. This longer interovulatory interval was not due to delayed luteolysis (Figures 4A and $4 \mathrm{~B}$ ) but was primarily the result of an increase of several days from luteolysis until ovulation (14.1 \pm 1.9 vs. $4.9 \pm 0.3 \mathrm{~d}$ ). At the time of luteolysis, almost all cows in either group were in the midst of their second follicular wave. Cows in the ovular group ovulated this second follicular wave, whereas atypical cows initiated a new follicular wave following luteolysis resulting a higher total number of follicular waves during the interovulatory interval in atypical cows $(2.9 \pm 0.1$ vs. $2.3 \pm 0.2$ waves). In contrast to our results, other investigators have reported extended interovulatory intervals due to delayed luteolysis (Savio et al., 1990a; Taylor and Rajamahendran, 1991; Kirby et al., 1997; Trout et al., 1998). Delayed ovulation in our cows is similar to reports of prolonged interluteal intervals (Nakao et al., 1992; Lamming and Darwash, 1998; Royal et al., 2000).

There were no apparent differences between typical and atypical cows for BCS ( $3.4 \pm 0.2$ vs. $3.0 \pm 0.1$, respectively), DIM ( $78.1 \pm 3.4$ vs. $81.7 \pm 7.3 \mathrm{~d})$, or milk production $(44.3 \pm 1.2$ vs. $44.8 \pm 2.7 \mathrm{~kg} / \mathrm{d})$, around the time of the first spontaneous ovulation that was detected after the beginning of ultrasound evaluation. Rectal temperature at the time of primary or secondary signs of estrus after luteolysis was also similar (39.2 \pm 0.2 vs. $39.3 \pm$ $0.3^{\circ} \mathrm{C}$ ). Reduced reproductive performance and development of anovulatory conditions in postpartum dairy cows have been correlated with several factors including lower BCS (Moreira et al., 2000), high milk production (Gröhn and Rajala-Schultz, 2000), or elevated body temperature related to infection (Peter et al., 1989; Schrick et al., 2001; Hockett et al., 2002). Similar percentages of anovular $(4$ of $9=44.4 \%)$ and ovular $(9$ of $14=64.3 \%)$ cows were observed in standing estrus during the first $5 \mathrm{~d}$ after luteolysis. Therefore, the ovulation failure following luteolysis that was observed in a high number of the cows evaluated in this study could not be explained by 

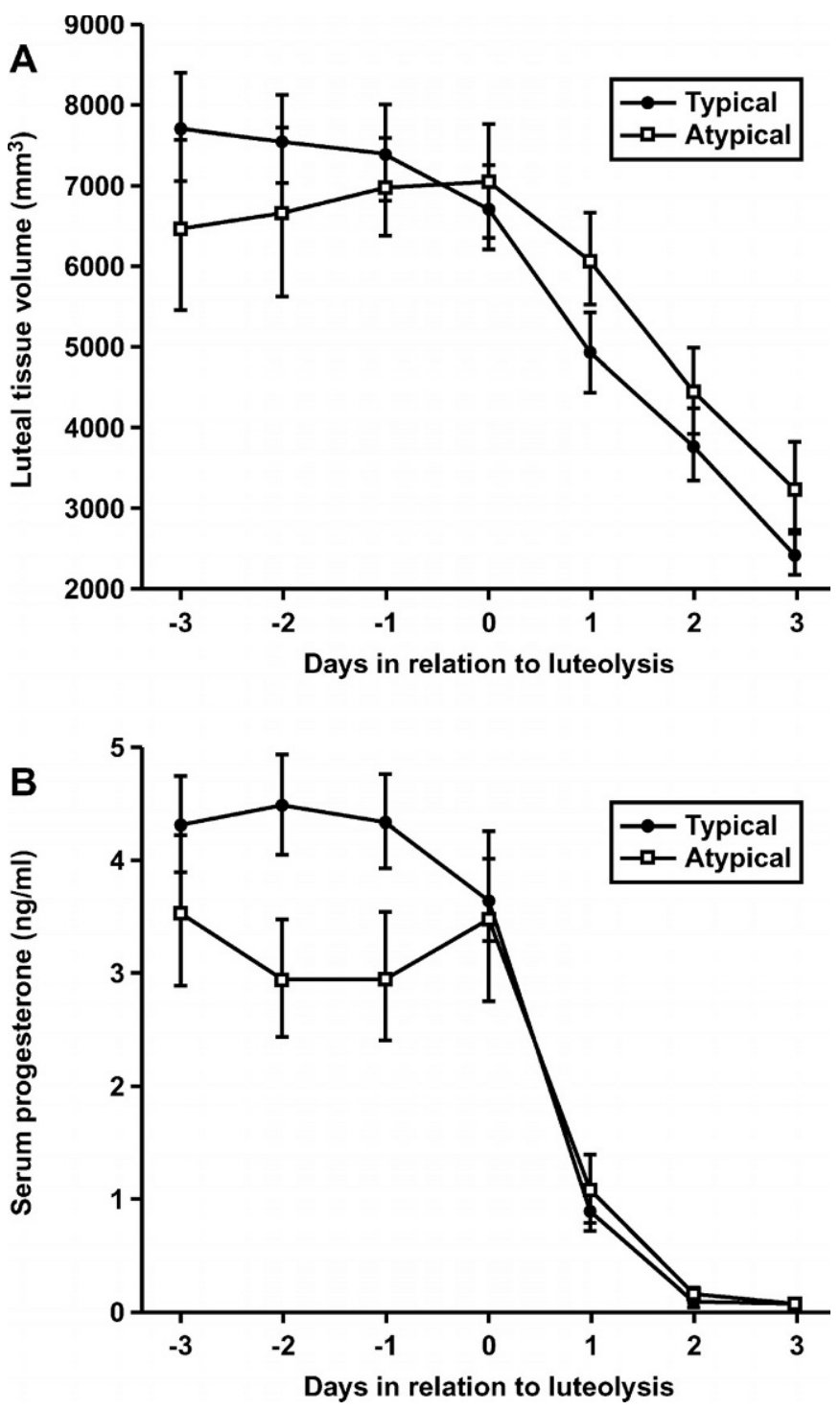

Figure 4. A. Luteal tissue volume. B. Serum progesterone concentration normalized to the time of luteolysis in lactating cows with typical $(n=14)$ and atypical $(n=9)$ cycles.

obvious differences in productivity, environmental conditions, or metabolic status of the females. Ovulation failure in some atypical cows that were detected in estrus and lack of detected estrus in some cows that ovulated illustrate that these 2 events are not necessarily dependent on each other.

Ovulation failure in atypical cows is most likely due to the lack of an LH surge, although this could not be determined using daily blood sampling. Incomplete or partial luteolysis, presence of luteinized ovarian structures, or progestational treatments are factors that can prevent ovulation by inhibiting the preovulatory $\mathrm{LH}$ surge (Lee et al., 1988; Sirois and Fortune, 1990; Silvia et al., 2002; Sartori and Wiltbank, unpublished observations). From Figure 4A and B, it seems clear that luteolysis was complete in all atypical and typical cows, as demonstrated by circulating $\mathrm{P}_{4}$ reaching nadir concentrations by $3 \mathrm{~d}$ after the initiation of CL regression. Therefore, incomplete CL regression does not appear to be the reason for ovulation failure in our study.

The incidence of codominant follicles in typical and atypical cows was evaluated during the first follicular wave, at the time of luteolysis, and during the ovulatory wave. Although, numerically, more typical cows showed codominance during the first wave (5/14 vs. $1 / 12)$ or at luteolysis (3/14 vs. 0/9), atypical cows had a higher incidence of multiple ovulation during the actual ovulatory wave (8/11 atypical cows vs. 3/14 typical cows). Within the group of cows with atypical cycles, incidence of codominance during the ovulatory wave was greater $(P<$ 0.05 ) than during the first wave, or at the time of luteolysis. Multiple ovulations in 20 to $40 \%$ of normal lactating cows is not uncommon (Fricke and Wiltbank, 1999; Santos et al., 2000; Vasconcelos et al., 2001), but 0\% codominance in atypical cows at luteolysis increasing to $73 \%$ multiple ovulation in the next follicular wave is intriguing and may be important in understanding mechanisms of multiple ovulation and codominance. Milk production and steroid metabolism could be key factors producing codominance in lactating dairy cows (Kinsel et al., 1998; Fricke and Wiltbank, 1999; Wiltbank et al., 2000). However, low $\mathrm{P}_{4}$ during selection of the dominant follicle appears to be the main difference between the ovulatory wave in atypical cows compared with other follicular waves in either atypical or typical cows. Others have observed high multiple ovulations in cows that developed the ovulatory follicular wave in the absence of $\mathrm{P}_{4}$ (Savio et al., 1990b; Gümen et al., Haughian et al., Lopez et al., and Sartori et al., unpublished observations). Similarly, a greater multiple ovulation rate was observed in sheep when $\mathrm{P}_{4}$ concentrations were reduced for $6 \mathrm{~d}$ before ovulation (Bartlewski, 2001). Thus, the endocrine environment and particularly circulating $\mathrm{P}_{4}$ concentration appear to have a principal effect on multiple ovulation rate either independent of or possibly contributing to effects of other factors, such as milk production.

Cows with typical or atypical cycles were similar for size of largest growing follicle at luteolysis, maximum size of largest growing follicle present near luteolysis, growth rate of the largest growing follicle, and size of largest single-ovulating follicle. A comparison of singleand multiple-ovulating typical cows showed that the maximal size of the ovulatory follicle for typical cows with single ovulation $(16.6 \pm 0.4 \mathrm{~mm} ; \mathrm{n}=11)$ was larger than either the maximal size of the largest ovulatory follicle $(14.0 \pm 1.0 \mathrm{~mm} ; \mathrm{n}=3)$ or the average maximal 
size of all ovulatory follicles $(12.9 \pm 0.7 \mathrm{~mm} ; \mathrm{n}=7)$ for typical cows with multiple ovulations. A similar trend was observed for the atypical cows, in which the maximal size of the ovulatory follicle for cows with single ovulation $(15.3 \pm 1.3 \mathrm{~mm} ; \mathrm{n}=3)$ was similar $(P=0.20)$ to the maximal size of the largest ovulatory follicle $(13.6 \pm 0.6$ $\mathrm{mm} ; \mathrm{n}=8)$, but was larger $(P=0.05)$ than the average maximal size of all ovulatory follicles $(12.4 \pm 0.5 \mathrm{~mm} ; \mathrm{n}=$ 18) for cows with multiple ovulations. Because follicular sizes were different between single- and multiple-ovulating cows, regardless of classification, data were presented only from cows with single-dominant follicles for Figure 5. Although the dominant follicle from atypical cows was, in general, smaller than from typical cows (Figure 5A), the growth rate of the follicles was similar between groups.

Serum $\mathrm{E}_{2}$ concentrations are presented using data from cows with single and multiple ovulations because serum $\mathrm{E}_{2}$ was similar between subgroups of cows with single-dominant or codominant follicles. One typical cow was, however, considered an outlier and was removed from the data set because of high $\left(>10 \mathrm{pg} / \mathrm{mL}\right.$ ) serum $\mathrm{E}_{2}$ concentrations, independent of day of the cycle. Despite continued growth of the dominant follicle in both typical and atypical cows, atypical cows did not have a detectable increase in circulating $\mathrm{E}_{2}$ following luteolysis (Figure 5), in contrast to the observed increase in circulating $\mathrm{E}_{2}$ following luteolysis in typical cows. Similarly, Hockett et al. (2002) reported that 8 of 12 cows with experimentally induced clinical mastitis did not have increased serum $\mathrm{E}_{2}$ despite continued growth of the follicle that failed to ovulate after luteolysis. However, in contrast to our study, none of those 8 cows displayed estrus. We normalized our data to peak serum $\mathrm{E}_{2}$ concentration within $5 \mathrm{~d}$ following luteolysis in cows that had cycles that were typical $(n=13)$ or atypical (nonovular wave; $\mathrm{n}=8$ ) and compared these to peak $\mathrm{E}_{2}$ in atypical cows near the time of ovulation (ovular wave; $n=8$ ). Typical cows had greater peak $\mathrm{E}_{2}(9.1 \pm 1.0 \mathrm{pg} / \mathrm{mL})$ than atypical cows during either the nonovular wave $(4.9 \pm 0.9 \mathrm{pg} / \mathrm{mL})$ or the ovular wave $(5.5 \pm 0.9 \mathrm{pg} / \mathrm{mL})$ but within atypical cows, peak $\mathrm{E}_{2}$ after luteolysis (nonovular wave) was not significantly different than peak $\mathrm{E}_{2}$ before ovulation (ovular wave). Although it is tempting to speculate that lower circulating $\mathrm{E}_{2}$ concentrations were responsible for delayed ovulation observed in this study, similarly low $\mathrm{E}_{2}$ concentrations were sufficient to induce ovulation in the subsequent follicular wave in atypical cows. Reasons for lower serum $\mathrm{E}_{2}$ concentrations in atypical cows in our study are not known.

Comparison of heifers vs. lactating cows with typical cycles. In the present study, nulliparous heifers and lactating cows had similar interovulatory intervals (22.0 and $22.9 \mathrm{~d}$, respectively; Table 1 ). This observation
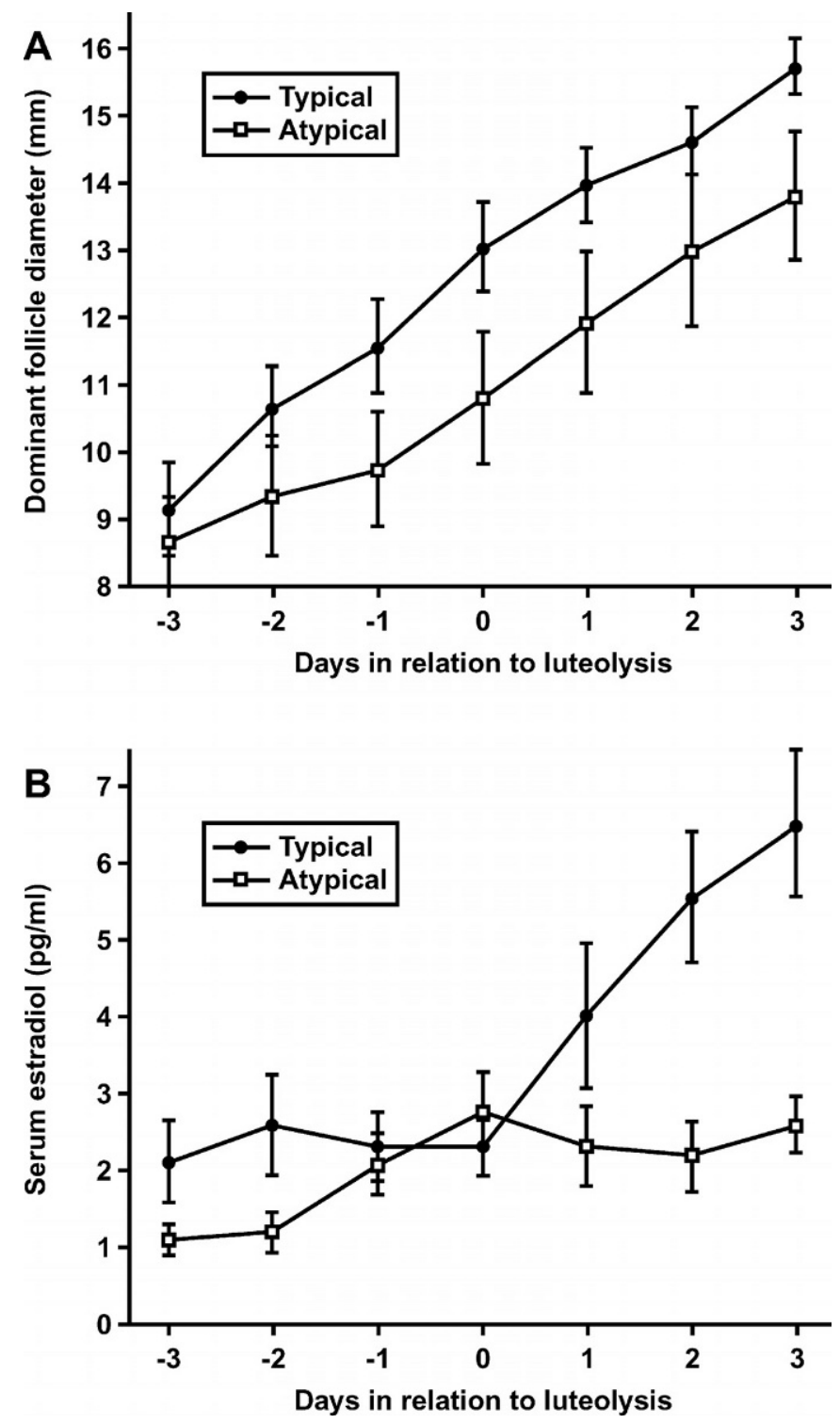

Figure 5. A. Size of the single-dominant follicle normalized to the time of luteolysis, in lactating cows with typical $(\mathrm{n}=11)$ and atypical $(\mathrm{n}=9)$ cycles, and B. Serum estradiol concentration normalized to the time of luteolysis, in lactating cows with typical $(\mathrm{n}=13)$ and atypical $(n=9)$ cycles.

contrasts with the results from Inbar et al. (2001), who reported a shorter interovulatory interval in heifers $(2.5$ $\mathrm{d}$ shorter). After extensive literature review, 7 studies that evaluated ovarian function in Holstein heifers were selected (Sirois and Fortune, 1988; Ginther et al., 1989; Knopf et al., 1989; Ko et al., 1991; Lucy et al., 1994; Wilson et al., 1998a; Ronchi et al., 2001), and 8 studies in lactating Holstein cows were selected (Savio et al., 1990a; Schemm et al., 1990; Taylor and Rajamahendran, 1991; Pursley et al., 1993; Kirby et al., 1997; Trout et al., 1998; Roth et al., 2000; Townson et al., 2002). Some 
Table 1. Comparisons between all (single- and multiple-ovulating) heifers $(\mathrm{n}=27)$ and lactating cows $(\mathrm{n}=$ 14) with typical cycles related to follicular waves, luteolysis, and ovulation. ${ }^{1}$

\begin{tabular}{llll}
\hline & Heifers & Cows & $P \leq$ \\
\hline Interovulatory interval (d) & $22.0 \pm 0.4(27)$ & $22.9 \pm 0.7(14)$ & 0.28 \\
Day of luteolysis & $18.5 \pm 0.4(27)$ & $18.9 \pm 0.6(14)$ & 0.53 \\
Cycles w/ 2 waves; \% (no./no.) & $55.6(15 / 27)$ & $78.6(11 / 14)$ & 0.15 \\
Cycles w/ 3 waves; \% (no./no.) & $33.3(9 / 27)$ & $14.3(2 / 14)$ & 0.19 \\
Cycles w/ 4 waves; \% (no./no.) & $11.1(3 / 27)$ & $7.1(1 / 14)$ & 0.68 \\
Day of emergence of second follicular wave & $8.9 \pm 0.3(27)$ & $11.1 \pm 0.6(14)$ & 0.0003 \\
Interval between emergence of last wave and ovulation & & & \\
(d) & $10.1 \pm 0.5(27)$ & $10.9 \pm 0.5(14)$ & 0.29 \\
Days from luteolysis to ovulation & $4.6 \pm 0.1(27)$ & $5.2 \pm 0.2(13)$ & 0.01 \\
Incidence of codominant follicles during first wave; \% & & & \\
(no./no.) & $3.7(1 / 27)$ & $35.7(5 / 14)$ & 0.01 \\
Multiple ovulation rate; \% (no./no.) & $1.9(1 / 54)$ & $17.9(5 / 28)$ & 0.02 \\
\hline
\end{tabular}

${ }^{1}$ All results are expressed as mean \pm SEM, except for percentages. Number of experimental units per group (shown within parentheses) vary.

of these studies evaluated the effect of bST or heat stress on ovarian function. By combining the results of all studies (treatment groups that altered ovarian function were not used for this analysis), a total of 230 cycles from 224 cows and 104 cycles from 97 heifers was obtained. The average interovulatory interval (or estrous cycle length) in lactating cows was $23.0 \mathrm{~d}$ and in heifers it was 20.8 $\mathrm{d}$. Interestingly, the interovulatory interval for lactating Holstein cows in our study and from the literature was about $2 \mathrm{~d}$ longer than the commonly accepted 21-d average.

A majority of animals from both groups had estrous cycles with 2 follicular waves, which was consistent with most of the reports of Holstein females in the literature (Ginther et al., 1989; Knopf et al., 1989; Ko et al., 1991; Taylor and Rajamahendran, 1991; Wilson et al., 1998a, 1998b; Roth et al., 2000; Inbar et al., 2001; Kulick et al., 2001; Townson et al., 2002). Cycles with 3 and 4 waves were also observed in heifers and cows (Table 1). No differences were detected between heifers and cows in the incidence of 2,3 , or 4 waves. The day of emergence of the second follicular wave was $2.2 \mathrm{~d}$ later in lactating cows than in heifers, but the day of luteolysis and the time period between emergence of the last wave and ovulation did not differ between groups (Table 1).

Most normal cycling females ovulated between 4 and $6 \mathrm{~d}$ after luteolysis. Most of the heifers (96.3\%) ovulated $4(\mathrm{n}=13)$ or $5 \mathrm{~d}(\mathrm{n}=13)$ after luteolysis, whereas most cows $(78.6 \%)$ ovulated $5(\mathrm{n}=7)$ or $6 \mathrm{~d}(\mathrm{n}=4)$ after luteolysis. Exceptions were one cow ovulating $2 \mathrm{~d}, 2$ cows ovulating $4 \mathrm{~d}$ and 1 heifer ovulating $6 \mathrm{~d}$ after luteolysis. The cow that ovulated $2 \mathrm{~d}$ after luteolysis deviated more than 2 standard deviations from the mean, was considered an outlier, and was not used for comparing days from luteolysis to ovulation between cows and heifers. On average, lactating cows took longer to ovulate after luteolysis than heifers (Table 1). This observation is con- sistent with the hypothesis that preovulatory follicles from lactating cows grow for a longer period under low circulating $\mathrm{P}_{4}$ concentrations than do preovulatory follicles in heifers. Investigators have reported that prolonged lifespan of the ovulatory follicle under low circulating $\mathrm{P}_{4}$ has resulted in reduced fertility (Mihm et al., 1994; Ahmad et al., 1995). Persistence of the dominant follicle is associated with prolonged exposure to increased concentrations of $\mathrm{E}_{2}$ before ovulation (Ahmad et al., 1996; Bigelow and Fortune, 1998), but it remains to be determined whether prolonged elevation in serum or intrafollicular concentrations of $\mathrm{E}_{2}$ before ovulation impairs fertility. Moreover, low serum $\mathrm{P}_{4}$ concentration allows increased pulse frequency of $\mathrm{LH}$ (Roberson et al., 1989; Bigelow and Fortune, 1998) that may cause premature maturation (resumption of meiosis) of the oocyte (Revah and Butler, 1996), and result in ovulation of an aged oocyte after the estradiol-induced GnRH/LH surge. Our study was not designed to evaluate LH pulsatility, but Vasconcelos et al. (unpublished observations) described greater $\mathrm{LH}$ pulses in lactating than in nonlactating nonpregnant dairy cows.

Codominant follicles or double ovulation were rare in estrous cycles of heifers. Out of 27 cycles and 54 ovulations evaluated, only one heifer had codominant follicles during the first wave. That heifer was the only one that had a double ovulation (Table 1; Figure 1B). Compared with heifers, cows with typical estrous cycles had a greater incidence of codominance (5/14) and multiple ovulations (5/28) (Table 1), albeit lower than the multiple ovulations among cows with delayed ovulation as discussed earlier. These results are consistent with the reported differences in twinning rate between heifers and lactating cows (Nielen et al., 1989; Kinsel et al., 1998; Wiltbank et al., 2000).

There was no difference between cows and heifers in the maximal size achieved by the largest dominant folli- 
Table 2. Results (mean \pm SEM) comparing all (single- and multiple-ovulating) heifers $(\mathrm{n}=27)$ and lactating cows (n $=14)$ with typical cycles for follicular and luteal development, and serum steroid concentrations.

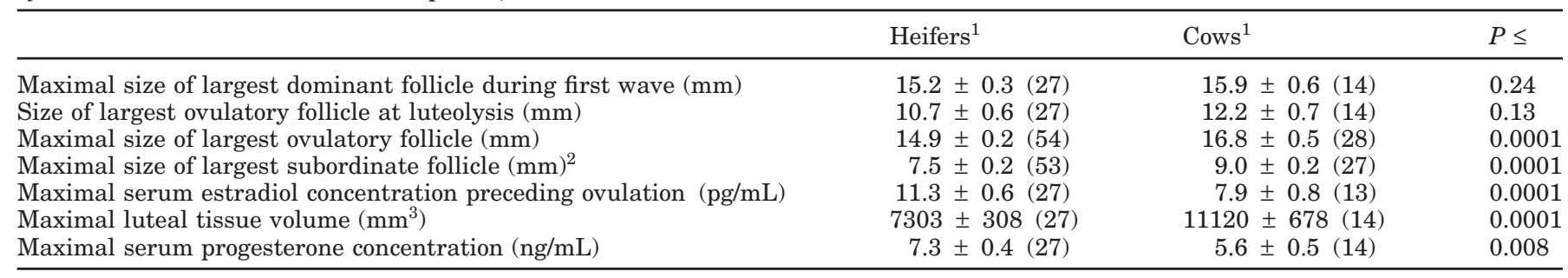

${ }^{1}$ Number of experimental units per group (shown within parentheses) vary.

${ }^{2}$ Combined data from first and last wave.

cle during the first follicular wave when all females (with single or codominant follicles) were compared (Table 2) or when only females with single-dominant follicles were compared (Table 3). There was also no difference within groups in maximal size of the largest dominant follicle between the first and the ovulatory wave. However, when the size of the largest ovulatory follicle was compared between groups, lactating cows ovulated larger follicles (Tables 2 and 3). Figure 6A and C illustrates differences in development of the dominant follicle during the ovulatory wave of single-ovulating dairy cows and heifers. When data were normalized to the day of luteolysis, lactating cows had larger follicles near the time of luteolysis (Figure 6A, Table 3). When data were normalized to the day of ovulation, larger dominant follicles were already observed in lactating cows by $6 \mathrm{~d}$ before ovulation (Figure 6C). Despite differences in size of the ovulatory follicle between heifers and cows, follicular growth rate was similar between groups (Table 3).

Despite having larger ovulatory follicles, lactating cows had lower maximal serum $\mathrm{E}_{2}$ concentration from luteolysis to ovulation either when all females (Table 2, Figure 6B and D) or only single ovulators (Table 3) were compared. Figure $6 \mathrm{~B}$ demonstrates that heifers had greater maximal concentration of $\mathrm{E}_{2}$ after luteolysis, and the peak was achieved earlier in heifers. When data were normalized to the day of ovulation, peak serum $\mathrm{E}_{2}$ occurred $2 \mathrm{~d}$ before detected ovulation in both groups, but cows still had lower $\mathrm{E}_{2}$ concentrations (data not shown). Other studies have also reported that lactating cows developed larger dominant/ovulatory follicles, but had lower serum $\mathrm{E}_{2}$ concentrations than heifers (Ahmad et al., 1996; Inbar et al., 2001) or dry cows (De La Sota et al., 1993). Lower circulating $\mathrm{E}_{2}$ in lactating cows could be related to either lower $\mathrm{E}_{2}$ production by follicles or to higher metabolism of $\mathrm{E}_{2}$ in lactating cows. There is no study that we are aware of that validly tested whether follicles of lactating cows have lower $\mathrm{E}_{2}$ production than heifers; however, Sangsritavong et al. (2002) demonstrated that lactating cows have a much greater steroid metabolism than nonlactating cows. Greater $\mathrm{E}_{2}$ metabolism would be expected to cause follicles in lactating cows to grow to larger sizes before sufficient $\mathrm{E}_{2}$ concentrations are reached to initiate the luteolytic cascade, or subsequently to induce the GnRH/LH surge and ovulation. Reduced preovulatory circulating $\mathrm{E}_{2}$ could be one of the main reasons for the altered reproductive physiology in lactating cows compared with nonlactating females. It may be associated with reduced length and/or intensity of behavioral estrus in lactating cows (Nebel et al., 1997; Dransfield et al., 1998), and may contribute to poor fertilization and poor early embryonic development (King et al., 1994; DeSouza and Murray, 1995). In addition, reduced peak $\mathrm{E}_{2}$ may also alter aspects of the $\mathrm{LH}$ surge that could account for ovulation failure following luteolysis

Table 3. Comparisons between heifers and lactating cows with typical estrous cycles that had single follicular dominance or single ovulation.

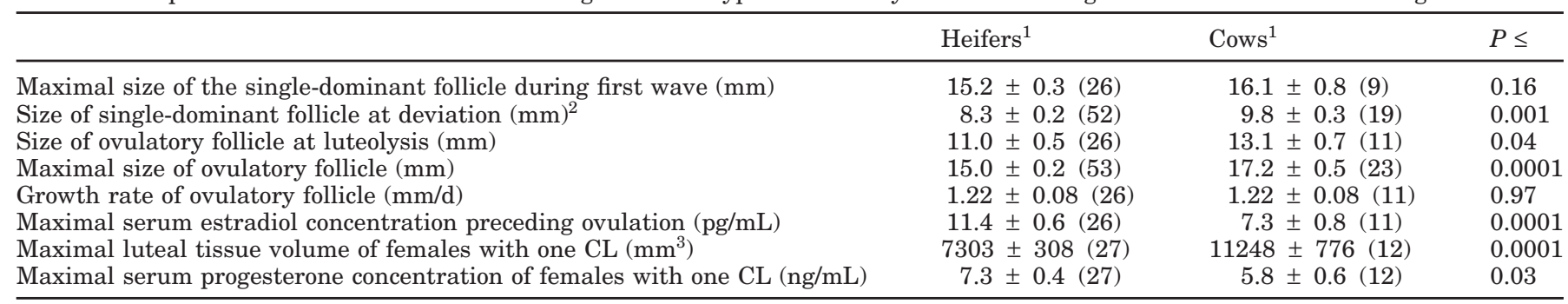

${ }^{1}$ Number of experimental units per group (shown within parentheses) vary.

${ }^{2}$ Combined data from first and last wave. 

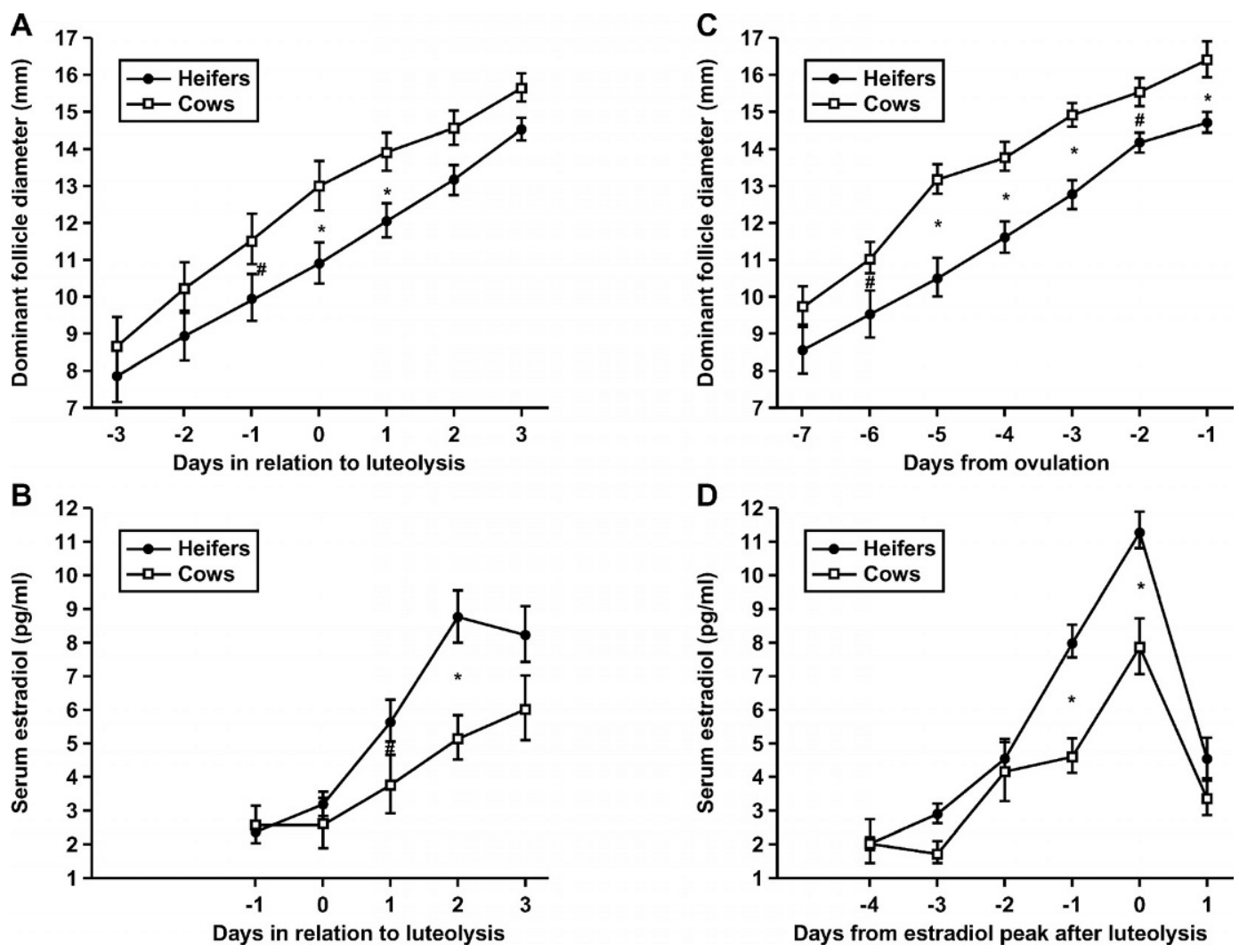

Figure 6. A. Size of the single-dominant follicle normalized to the time of luteolysis in heifers $(\mathrm{n}=26)$ and lactating cows $(\mathrm{n}=11)$. B. Serum estradiol concentration normalized to the time of luteolysis in heifers $(n=27)$ and lactating cows $(n=13)$. C. Size of the singledominant follicle normalized to the time of ovulation in heifers $(n=26)$ and lactating cows $(n=11)$. D. Maximal serum estradiol concentration within $5 \mathrm{~d}$ following luteolysis in heifers $(\mathrm{n}=27)$ and lactating cows $(\mathrm{n}=13) . * P<0.05$; $\# P<0.10$ for comparisons between groups within days.

in lactating cows as observed in this and other studies (Hockett et al., 2002; Wiltbank et al., 2002).

Differences existed between lactating cows and heifers in follicle sizes at the time of follicular selection. Similar to other reports in the literature (Ginther et al., 1996; Ginther, 2000), size of the single-dominant follicle at the time of follicular deviation either during the first or last wave in heifers averaged $8.3 \mathrm{~mm}$ in diameter (Table 3). However, the average diameter of the dominant follicle at the time of deviation was $1.6 \mathrm{~mm}$ larger for lactating cows (Table 3). In addition, the average maximal size achieved by the largest subordinate follicle was $1.5 \mathrm{~mm}$ larger in lactating cows (Table 2). This observation suggests that mechanisms involved in follicular deviation may be altered in lactating cows. There were no detectable differences between average maximal size achieved by the largest subordinate follicle during the first vs. last wave when comparisons were made within heifers or lactating cows.

Lactating cows developed more luteal tissue volume than heifers, as shown in Table 2 and Figure 7A. Figure 7A illustrates the CL development in lactating cows and heifers from d 3 to 14 of the estrous cycle and shows that differences in CL volume between cows and heifers could be detected by d 4 of the cycle. Larger CL in cows are probably a consequence of ovulation of larger follicles as demonstrated by the positive correlation between size of the ovulatory follicle and luteal tissue volume (Vasconcelos et al., 2001). Moreover, larger CL in cows were not due to higher incidence of multiple ovulation because when females with one CL were compared, lactating cows still developed more luteal tissue than heifers (Table 3). In spite of the greater luteal tissue volume in cows, regressed CL were similar in size for cows and heifers at $3 \mathrm{~d}$ after luteolysis (Figure $8 \mathrm{~A}$ ) or by $3 \mathrm{~d}$ before ovulation (Figure $8 \mathrm{C}$ ).

Serum $\mathrm{P}_{4}$ concentration was lower in cows than in heifers (Table 2 and Figure 7B) despite larger luteal tissue volume in cows. Heifers had a greater peak concentration of circulating $\mathrm{P}_{4}$ than cows during the cycle either when all females were compared (Table 2 ) or when females with only one CL were compared (Table 3). Differences in circulating $\mathrm{P}_{4}$ between heifers and cows were first detected on $d 6$ of the cycle and persisted until the 

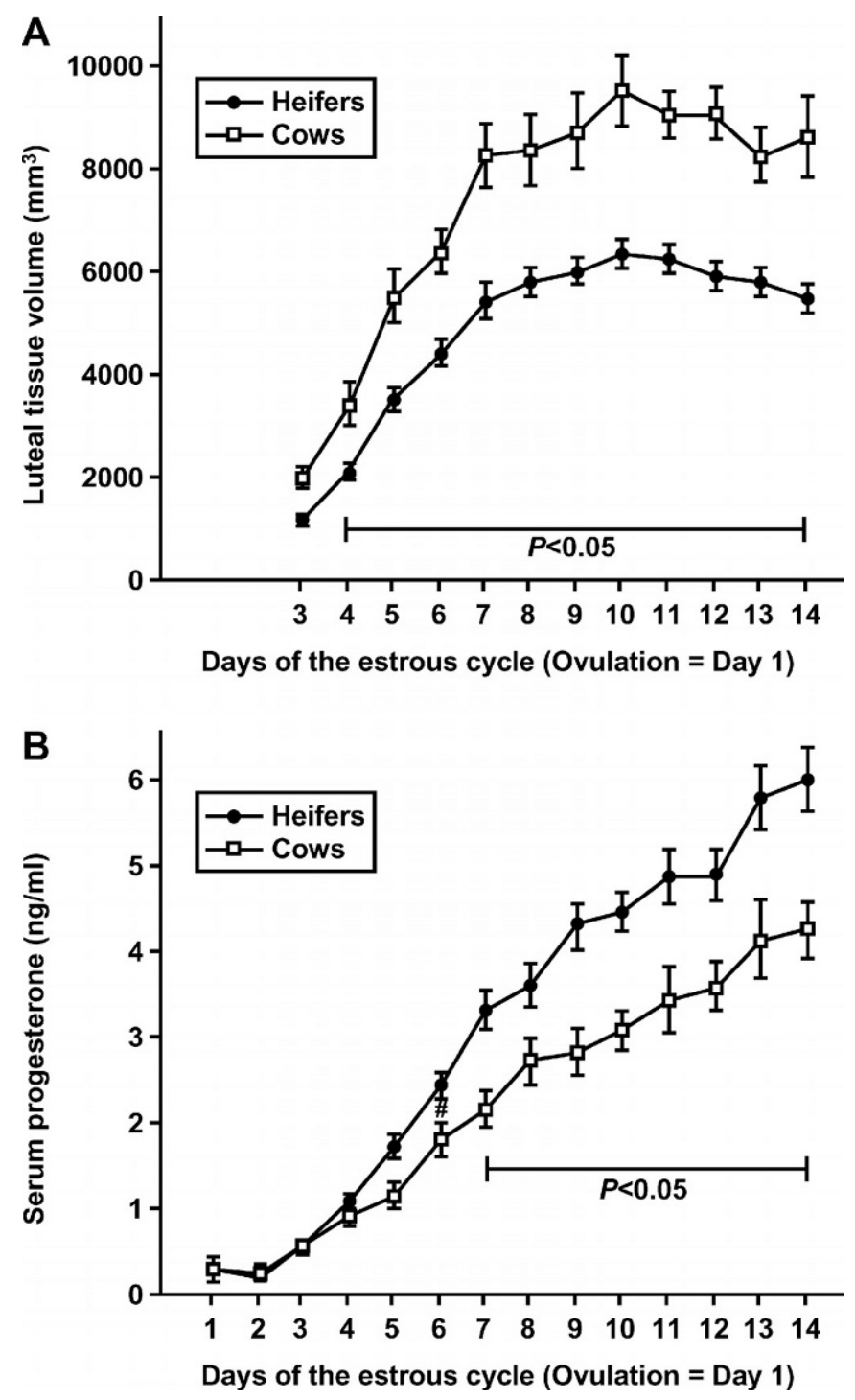

Figure 7. A. Luteal tissue volume. B. Serum progesterone concentration from d 3 to 14 and $d 1$ to 14 of the estrous cycle, respectively, in heifers $(\mathrm{n}=27)$ and lactating cows $(\mathrm{n}=14)$. $\# P<0.10$ for comparisons between groups within days.

day of luteolysis (Figures 7B and 8B). Similarly, Inbar et al. (2001) reported greater $\mathrm{P}_{4}$ concentrations in heifers than cows after $d 2$ of the cycle, and De La Sota et al. (1993) reported lower circulating $\mathrm{P}_{4}$ concentrations in lactating compared with nonlactating cows. The CL volume reached a plateau around $\mathrm{d} 7$ or 8 of the cycle, whereas serum $\mathrm{P}_{4}$ continued to rise until $\mathrm{d} 14$ in animals from both groups (Figure 7). There seems to be substantial fluctuation in the $\mathrm{P}_{4}$ concentrations from $\mathrm{d} 7$ to 14 when profiles of individual cows (Figures 1 to 3 ) are analyzed; however, these individual fluctuations result in a steady mean increase in circulating $\mathrm{P}_{4}$ (Figure 7B). The bovine CL apparently continues to increase in ste- roidogenic capacity during the second half of the luteal phase in the absence of increasing luteal volume. Figure $8 \mathrm{D}$ shows the decrease in circulating $\mathrm{P}_{4}$ during the last $7 \mathrm{~d}$ preceding ovulation in heifers and cows. Lower circulating $\mathrm{P}_{4}$ concentrations in cows than in heifers continues to be evident as luteolysis approaches and a longer period between luteolysis and ovulation is also apparent. The mechanisms producing the lower circulating $\mathrm{P}_{4}$ in lactating cows may be similar to the mechanisms producing lower circulating $\mathrm{E}_{2}$. Increased steroid metabolism may be an important part of this mechanism because continuous infusion of $\mathrm{P}_{4}$ at a constant rate produced much greater circulating $\mathrm{P}_{4}$ concentrations in dry cows than in lactating cows of similar size (Sangsritavong et al., 2002). Alternatively, there may be a difference in $\mathrm{P}_{4}$ production or diminished response to circulating luteotrophic hormones in the lactating cows, as suggested by Shelton et al. (1990). As reported in several manuscripts, reduced serum concentration of $\mathrm{P}_{4}$ either before (Folman et al., 1973; Fonseca et al., 1983) or after (Mann et al., 1995; Ahmad et al., 1996) ovulation may have major effects on fertility. Low serum concentration of $\mathrm{P}_{4}$ before ovulation may compromise oocyte integrity, as discussed earlier, and lower circulating $\mathrm{P}_{4}$ after ovulation may hamper early embryonic development (Mann et al., 1998).

Comparisons among heifers with 3 follicular waves, heifers with 2 follicular waves, and lactating cows with 2 follicular waves. It is well established that heifers or cows with 3 follicular waves tend to have a longer interovulatory interval than females of the same category with 2 waves (Savio et al., 1988, 1990; Sirois and Fortune, 1988; Ginther et al., 1989; Knopf et al., 1989; Taylor and Rajamahendran, 1991; Ahmad et al., 1997; Townson et al., 2002). Consistent with this observation, 3-wave heifers had a longer interovulatory interval than 2 -wave heifers in the present study as a consequence of delayed time of luteolysis (Table 4). Other studies in dairy heifers or cows have also reported a longer "luteal phase" for 3- vs. 2-wave females (Ginther et al., 1989; Gong et al., 1993; Ahmad et al., 1997; Townson et al., 2002). Although cows with 2 waves had longer interovulatory intervals than heifers with 2 waves, these 2 groups did not statistically differ in the day of luteolysis (Table 4). Interovulatory interval and day of luteolysis from 2-wave cows did not differ from 3-wave heifers (Table 4). The interval between emergence of last follicular wave and ovulation was about $4 \mathrm{~d}$ shorter in 3-wave heifers than either 2-wave cows or heifers. However, 2wave heifers had a shorter interval from luteolysis to ovulation than the other 2 groups (Table 4). Townson et al. (2002) also observed a shorter interval from luteolysis to ovulation in 2 -wave cows. The day of emergence of the second follicular wave occurred earlier in 3-wave 

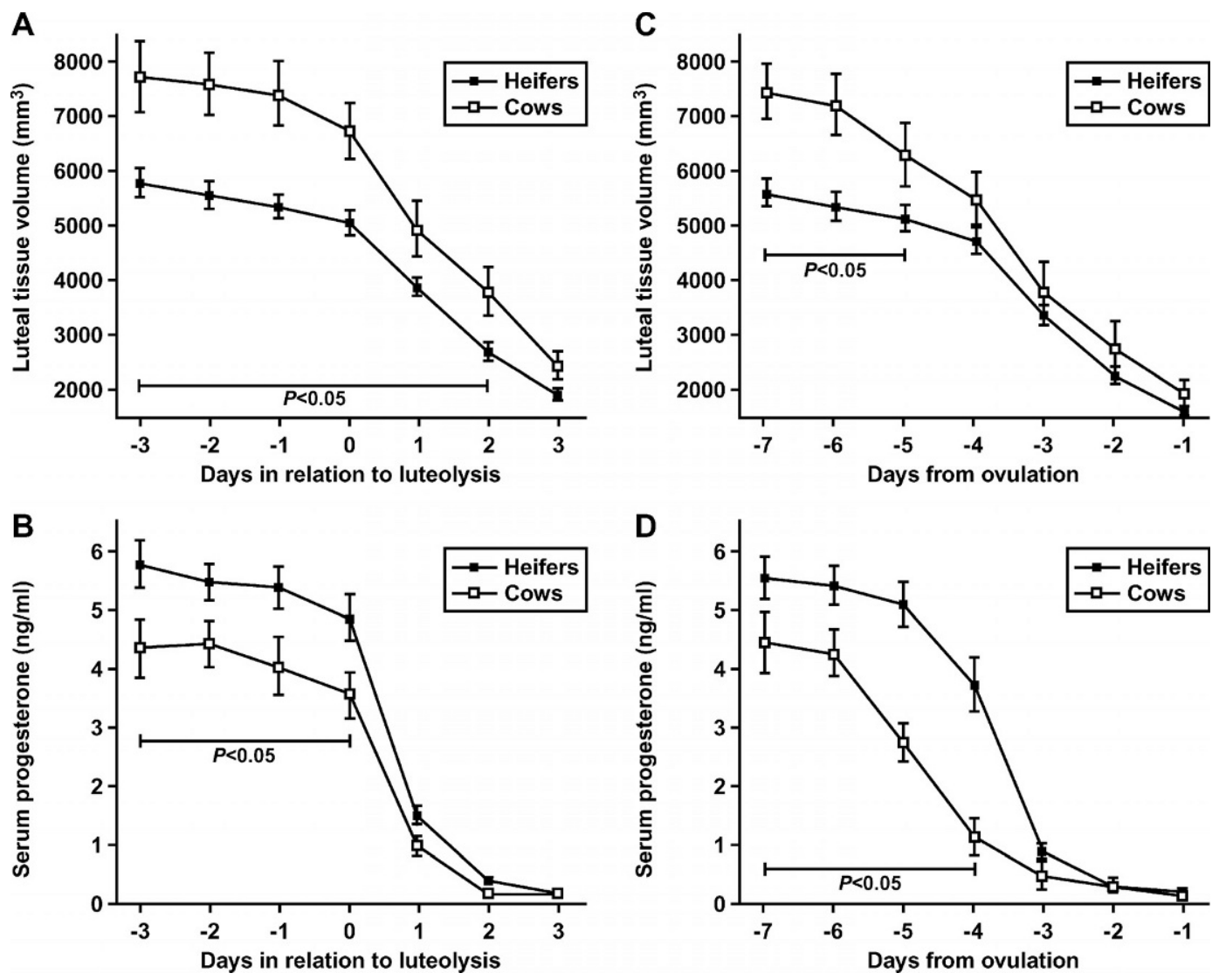

Figure 8. A. Luteal tissue volume. B. Serum progesterone concentration normalized to the time of luteolysis in heifers $(\mathrm{n}=27)$ and lactating cows $(\mathrm{n}=14)$. C. Luteal tissue volume and D. Serum progesterone concentration normalized to the time of ovulation in heifers $(\mathrm{n}=27)$ and lactating cows $(\mathrm{n}=14)$. $\# P<0.10$ for comparisons between groups within days.

heifers and later in 2-wave cows (Table 4). The time of emergence of the third follicular wave in 3 -wave heifers (16.3 d) was similar to other reports (Savio et al., 1988; Sirois and Fortune, 1988; Ginther et al., 1989; Ko et al., 1991; Gong et al., 1993).

The maximal size of the largest dominant follicle during the first and ovulatory waves was smaller for 3wave heifers (14.6 \pm 0.4 and $14.6 \pm 0.4 \mathrm{~mm}$, respectively) compared with 2 -wave cows $(16.5 \pm 0.7$ and $16.1 \pm 0.5$ $\mathrm{mm}$, respectively), with intermediate sizes for 2 -wave heifers $(15.7 \pm 0.4$ and $15.2 \pm 0.3 \mathrm{~mm}$, respectively). Townson et al. (2002) reported larger ovulatory follicles in cows with 2 vs. 3 follicular waves. In comparisons within groups, there was no difference between the maximal size of the largest dominant follicle during the first wave and the ovulatory wave, but the follicle from the

Table 4. Results (mean \pm SEM) comparing heifers with three follicular waves $(n=9)$, heifers with two follicular waves $(\mathrm{n}=15)$, and lactating cows with two follicular waves $(\mathrm{n}=11)$ related to follicular waves, luteolysis, and ovulation.

\begin{tabular}{lccc}
\hline & 3-Wave heifers & 2-Wave heifers & 2-Wave cows \\
\hline Interovulatory interval (d) & $23.1 \pm 0.7^{\mathrm{b}}$ & $20.7 \pm 0.3^{\mathrm{a}}$ & $21.9 \pm 0.7^{\mathrm{b}}$ \\
Day of luteolysis & $19.1 \pm 0.6^{\mathrm{b}}$ & $17.4 \pm 0.3^{\mathrm{a}}$ & $18.1 \pm 0.5^{\mathrm{ab}}$ \\
Day of emergence of second follicular wave & $8.2 \pm 0.4^{\mathrm{a}, \mathrm{A}}$ & $9.7 \pm 0.2^{\mathrm{a}, \mathrm{B}}$ & $11.5 \pm 0.6^{\mathrm{b}, \mathrm{C}}$ \\
Interval between emergence of last wave and & $7.8 \pm 0.6^{\mathrm{a}}$ & $12.0 \pm 0.3^{\mathrm{b}}$ & $11.4 \pm 0.6^{\mathrm{b}}$ \\
ovulation (d) & $16.3 \pm 0.6$ & - & $-{ }^{\mathrm{b}}$ \\
Day of emergence of third follicular wave & $5.0 \pm 0.2^{\mathrm{b}}$ & $4.3 \pm 0.1^{\mathrm{a}}$ & $5.1 \pm 0.2^{\mathrm{b}}$ \\
\hline
\end{tabular}

${ }^{\mathrm{a}, \mathrm{b}}$ Different within each row; $P<0.05$.

A,B,C Tended to differ within each row; $P<0.10$. 

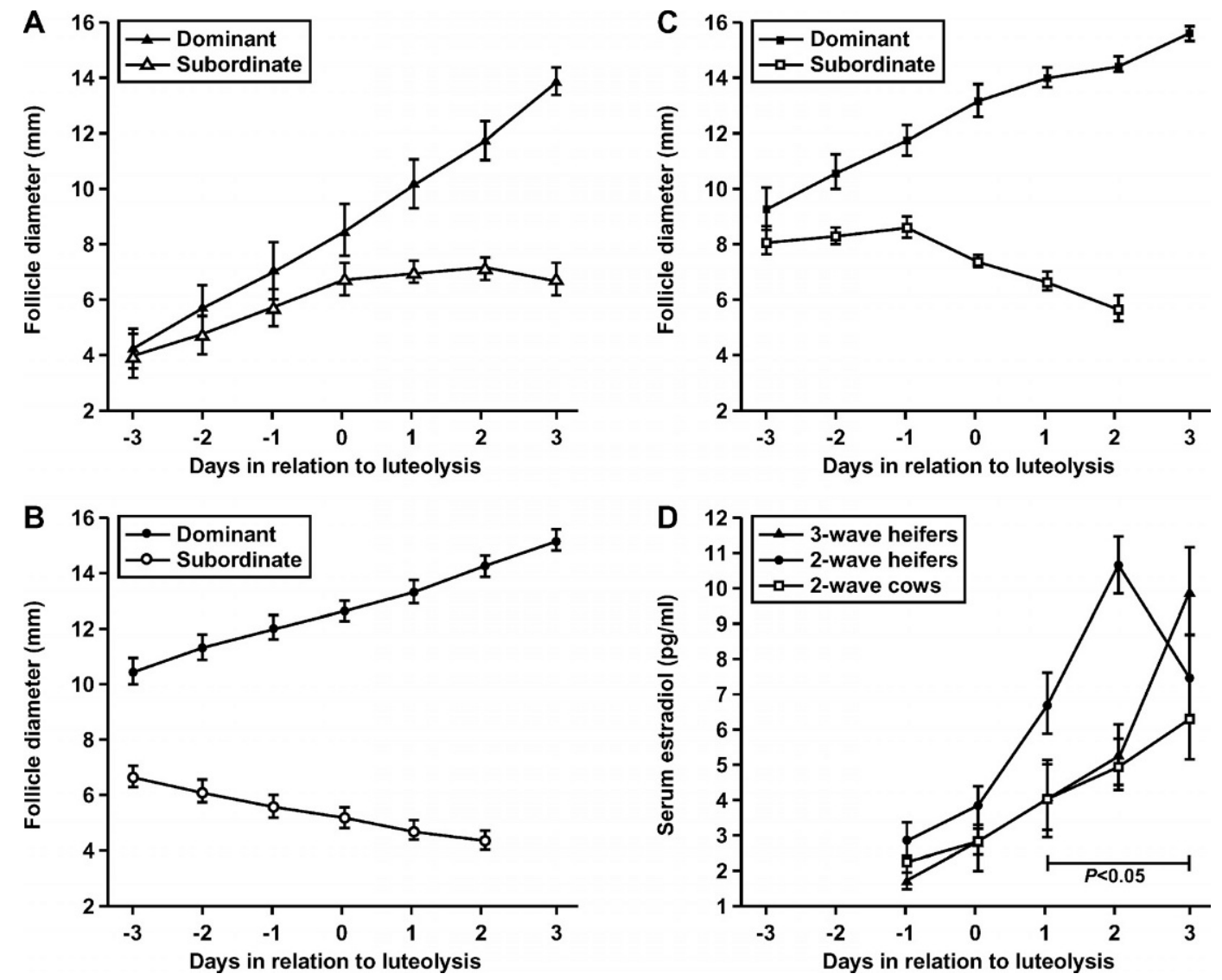

Figure 9. Size of the single-dominant and largest subordinate follicle normalized to the time of luteolysis in A. Heifers with 3 follicular waves $(n=8)$, B. Heifers with 2 follicular waves $(n=15)$, and C. Lactating cows with 2 follicular waves $(n=9)$. D. Serum estradiol concentration normalized to the time of luteolysis in heifers with 3 follicular waves $(n=9)$, heifers with 2 follicular waves $(n=15)$, and lactating cows with 2 follicular waves $(\mathrm{n}=11)$.

second wave in 3-wave heifers was smaller (12.2 \pm 0.6 $\mathrm{mm})$. The size of the future ovulatory follicle at the time of luteolysis was smaller in 3-wave heifers $(8.1 \pm 0.9$ $\mathrm{mm})$ but was similar between 2 -wave heifers $(12.6 \pm 0.4$ $\mathrm{mm})$ and cows $(12.6 \pm 0.7 \mathrm{~mm})$ (Figure 9). For heifers with 3 waves, follicular deviation occurred near the time of luteolysis (Figure 9A) in contrast to follicular deviation several days (2-wave heifers; Figure 9B) or $\sim 1 \mathrm{~d}$ (2-wave cows; Figure 9C) before luteolysis.

When only single-ovulating females were compared, maximal size of the ovulatory follicle was larger in 2wave cows $(16.4 \pm 0.5 \mathrm{~mm})$ than 3 -wave heifers $(14.6 \pm$ $0.5 \mathrm{~mm})$ and tended $(P<0.10)$ to be larger in 2 -wave cows than 2-wave heifers (15.2 $\pm 0.6 \mathrm{~mm})$ (Figure 10A). There was no difference in growth rate of the largest ovulatory follicle between cows and heifers with 2 follicular waves $(1.20 \pm 0.07$ and $0.95 \pm 0.04 \mathrm{~mm} / \mathrm{d}$, respectively), but the ovulatory follicle from 3 -wave heifers grew at a faster rate $(1.74 \pm 0.17 \mathrm{~mm} / \mathrm{d})$ (Figure 10A). This explains the shorter time period from emergence of the last follicular wave and ovulation, despite similar maximal sizes of the ovulatory follicle between heifers with 2 and 3 waves. Ahmad et al. (1997) reported a growth rate of 1.0 and $1.5 \mathrm{~mm} / \mathrm{d}$ for the ovulatory follicle from beef heifers or cows with 2 and 3 follicular waves, respectively; however, Townson et al. (2002) observed a similar growth rate $(1.2 \mathrm{~mm} / \mathrm{d})$ of the ovulatory follicle in 2- or 3-wave lactating dairy cows.

Patterns of serum concentration of $\mathrm{E}_{2}$ near the time of luteolysis were also very distinct among groups (Figure 9D). Circulating $\mathrm{E}_{2}$ was similar among groups at luteolysis but $\mathrm{E}_{2}$ increased earlier after luteolysis in 2wave heifers, whereas 2 -wave cows had a more delayed and less pronounced rise in circulating $\mathrm{E}_{2}$. Maximal serum $\mathrm{E}_{2}$ after luteolysis was greater in heifers than cows, and tended to be greater in 2- vs. 3-wave heifers (Figure 10B).

Lactating cows had lower peak serum $\mathrm{P}_{4}$ concentration $(5.3 \pm 0.5 \mathrm{ng} / \mathrm{mL})$ than heifers with $2(7.1 \pm 0.5 \mathrm{ng} / \mathrm{mL})$ or $3(7.7 \pm 0.7 \mathrm{ng} / \mathrm{mL})$ follicular waves, in spite of having larger CL. Differences in luteal tissue volume (Figure 11A) and circulating $\mathrm{P}_{4}$ (Figure 11B) between cows and 

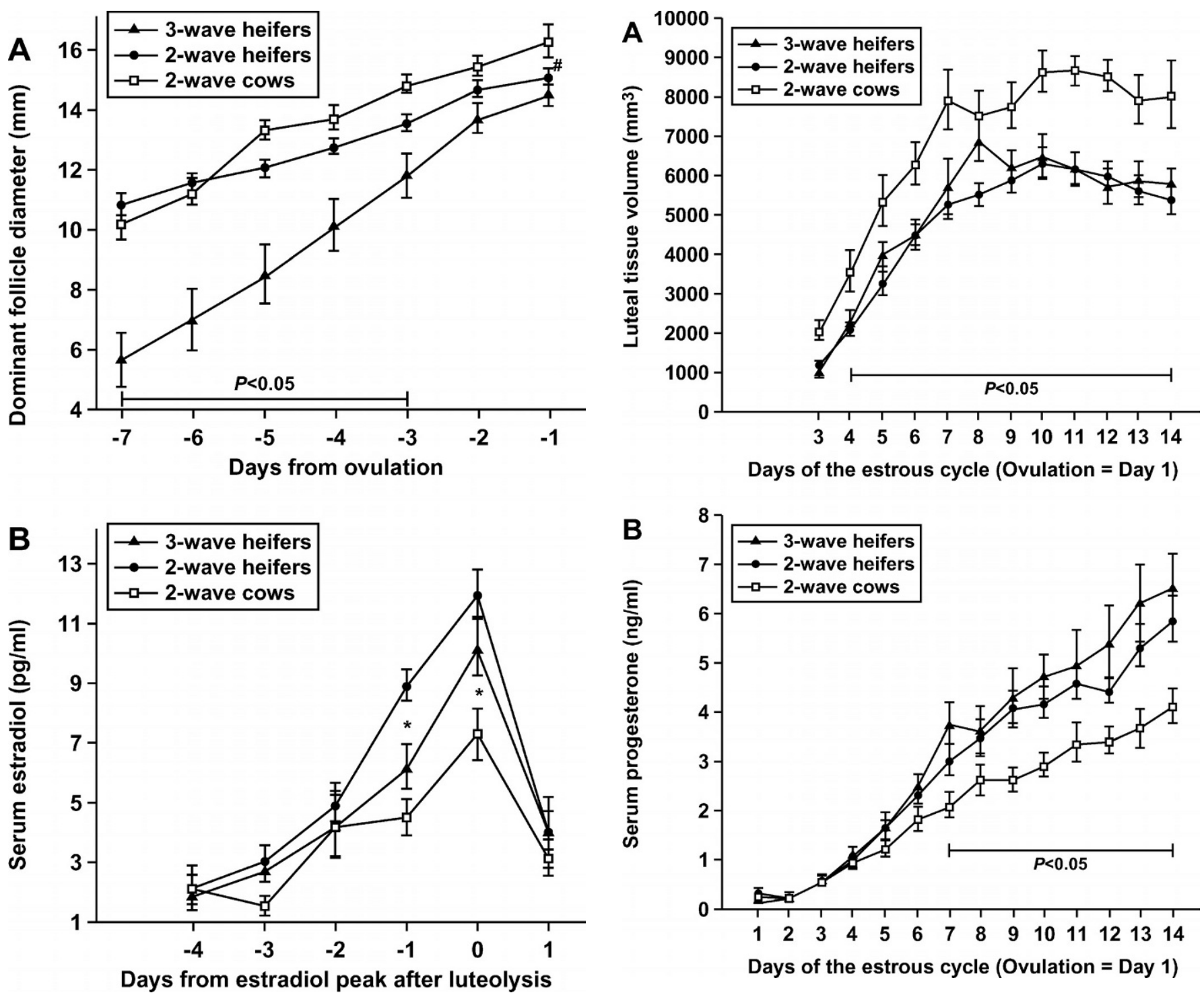

Figure 10. A. Size of the single-ovulatory follicle near the time of ovulation in heifers with 3 follicular waves $(n=8)$, heifers with 2 follicular waves $(n=15)$, and lactating cows with 2 follicular waves $(n=9)$. B. Maximal serum estradiol concentration after luteolysis in heifers with 3 follicular waves $(n=9)$, heifers with 2 follicular waves ( $\mathrm{n}=15)$, and lactating cows with 2 follicular waves $(\mathrm{n}=11) . * P<$ 0.05 ; $\# P<0.10$ for comparisons between groups within days.

heifers were first detected on $\mathrm{d} 4$ and 7 of the estrous cycle, respectively, and persisted until the day of luteolysis, with the exception of $\mathrm{d} 8$. On $\mathrm{d} 8$, there was no detectable difference in CL volume between 2 -wave cows and 3-wave heifers, and this was the only time point in which there was a difference in CL size between heifers with 2 vs. 3 waves (Figure 11A). Similar to what was observed in lactating dairy cows with 2 vs. 3 waves (Townson et al., 2002), no differences were detected between heifers with 2 and 3 waves in circulating $\mathrm{P}_{4}$ until

Figure 11. A. Luteal tissue volume. B. Serum progesterone concentration from d 3 to 14 and $\mathrm{d} 1$ to 14 of the estrous cycle, respectively, in heifers with 3 follicular waves $(\mathrm{n}=9$ ), heifers with 2 follicular waves $(n=15)$, and lactating cows with 2 follicular waves $(n=11)$.

d 14 of the cycle (Figure 11B). When data were normalized to the time of luteolysis or ovulation, 2-wave lactating cows continued to show a lower circulating $\mathrm{P}_{4}$ concentration than heifers but a larger luteal volume (data not shown). Nevertheless, the pattern of luteal regression, in terms of CL size and circulating $\mathrm{P}_{4}$, was similar in all 2 groups, although lactating cows with 2 waves had a longer period from luteolysis until ovulation than 2wave heifers, and 3-wave heifers were intermediate. By $3 \mathrm{~d}$ before ovulation, there were no differences among groups in CL volume or circulating $\mathrm{P}_{4}$, suggesting complete luteolysis in females from all 3 subgroups. 


\section{CONCLUSIONS}

Lactating cows had a much greater incidence of ovulation failure after luteolysis and multiple ovulations than did heifers during this study. Moreover, normally ovulating lactating cows had lower serum steroid concentrations than heifers in spite of having larger ovulatory follicles and CL. These differences between lactating cows and heifers were not explained by differences in patterns of follicular waves. Discrepancies between sizes of ovarian structures and serum steroid concentrations may be due to greater steroid metabolism in lactating cows. Lower serum steroid concentrations have numerous potential physiological consequences that may compromise reproduction in lactating cows.

\section{ACKNOWLEDGMENTS}

This research was supported by Wisconsin State Experiment Station, USDA grant 2000-2276, and the fellowship BEX 1811/97-5 from CAPES of Brazil to Roberto Sartori.

\section{REFERENCES}

Ahmad, N., F. N. Schrick, R. L. Butcher, and E. K. Inskeep. 1995. Effect of persistent follicles on early embryonic losses in beef cows. Biol. Reprod. 52:1129-1135.

Ahmad, N., S. W. Beam, W. R. Butler, D. R. Deaver, R. T. Duby, D. R. Elder, J. E. Fortune, L. C. Griel, L. S. Jones, R. A. Milvae, J. L. Pate, I. Revah, D. T. Schreiber, D. H. Townson, P. C. W. Tsang, and E. K. Inskeep. 1996. Relationship of fertility to patterns of ovarian follicular development and associated hormonal profiles in dairy cows and heifers. J. Anim. Sci. 74:1943-1952.

Ahmad, N., E. C. Townsend, R. A. Dailey, and E. K. Inskeep. 1997. Relationships of hormonal patterns and fertility to occurrence of two or three waves of ovarian follicles, before and after breeding, in beef cows and heifers. Anim. Reprod. Sci. 49:13-28.

Bartlewski, P. M. 2001. The relationships between ovarian antral follicle dynamics, luteal function and endocrine variables in ewes. Ph.D. Diss., Univ. of Saskatchewan, Canada.

Bigelow, K. L., and J. E. Fortune. 1998. Characteristics of prolonged dominant versus control follicles: follicle cell numbers, steroidogenic capabilities, and messenger ribonucleic acid for steroidogenic enzymes. Biol. Reprod. 58:1241-1249.

De La Sota, R. L., M. C. Lucy, C. R. Staples, and W. W. Thatcher. 1993. Effects of recombinant bovine somatotropin (Sometribove) on ovarian function in lactating and nonlactating dairy cows. J. Dairy Sci. 76:1002-1013.

DeSouza, M. M., and M. K. Murray. 1995. An estrogen-dependent secretory protein, which shares identity with chitinases, is expressed in a temporally and regionally specific manner in the sheep oviduct at the time of fertilization and embryo development. Endocrinology 136:2485-2496.

Dransfield, M. G. B., R. L. Nebel, R. E. Pearson, and L. D. Warnick. 1998. Timing of insemination for dairy cows identified in estrus by a radiotelemetric estrus detection system. J. Dairy Sci. 81:1874-1882.

Folman, Y., M. Rosenberg, Z. Herz, and M. Davidson. 1973. The relationship between plasma progesterone concentration and conception in post-partum dairy cows maintained on two levels of nutrition. J. Reprod. Fertil. 34:267-278.

Fonseca, F. A., J. H. Britt, B. T. McDaniel, J. C. Wilk, and A. H. Rakes. 1983. Reproductive traits of Holstein and Jerseys. Effects of age, milk yield, and clinical abnormalities on involution of cervix and uterus, ovulation, estrous cycles, detection of estrus, conception rate, and days open. J. Dairy Sci. 66:1128-1147.

Fricke, P. M., and M. C. Wiltbank. 1999. Effect of milk production on the incidence of double ovulation in dairy cows. Theriogenology 52:1133-1143.

Garverick, H. A. 1997. Ovarian follicular cysts in dairy cows. J. Dairy Sci. 80:995-1004.

Ginter, O. J. 2000. Selection of the dominant follicle in cattle and horses. Anim. Reprod. Sci. 60-61:61-79.

Ginter, O. J., L. Knopf, and J. P. Kastelic. 1989. Temporal associations among ovarian events in cattle during oestrous cycles with two and three follicular waves. J. Reprod. Fertil. 87:223-230.

Ginther, O. J., M. C. Wiltbank, P. M. Fricke, J. R. Gibbons, and K. Kot. 1996. Selection of the dominant follicle in cattle. Biol. Reprod. 55:1187-1194.

Gong, J. G., T. A. Bramley, and R. Webb. 1993. The effect of recombinant bovine somatotrophin on ovarian follicular growth and development in heifers. J. Reprod. Fertil. 97:247-254.

Gröhn, Y. T., and P. J. Rajala-Schultz. 2000. Epidemiology of reproductive performance in dairy cows. Anim. Reprod. Sci. 60-61:605-614.

Hockett, M. E., N. R. Rohrbach, R. A. Almeida, S. P. Oliver, and F. N. Schrick. 2002. Effects of experimentally-induced clinical mastitis during the preovulatory period on endocrine function, follicular growth and ovulation in lactating dairy cows. J. Dairy Sci. 85(Suppl. 1):265. (Abstr.)

Inbar, G., D. Wolfenson, Z. Roth, M. Kaim, A. Bloch, and R. BrawTal. 2001. Follicular dynamics and concentrations of steroids and gonadotropins in lactating cows and nulliparous heifers. J. Dairy Sci. 84(Suppl. 1):465. (Abstr.)

King, R. S., S. H. Anderson, and G. J. Killian. 1994. Effect of bovine oviductal estrus-associated protein on the ability of sperm to capacitate and fertilize oocytes. J. Androl. 15:468-478.

Kinsel, M. L., W. E. Marsh, P. L. Ruegg, and W. G. Etherington. 1998. Risk factors for twinning in dairy cows. J. Dairy Sci. 81:989-993.

Kirby, C. J., M. F. Smith, D. H. Keisler, and M. C. Lucy. 1997. Follicular function in lactating dairy cows treated with sustained-release bovine somatotropin. J. Dairy Sci. 80:273-285.

Knopf, L., J. P. Kastelic, E. Schallenberger, and O. J. Ginther. 1989. Ovarian follicular dynamics in heifers: Test of two-wave hypothesis by ultrasonically monitoring individual follicles. Domest. Anim. Endocrinol. 6:111-119.

Ko, J. C. H., J. P. Kastelic, M. R. Del Campo, and O. J. Ginther. 1991. Effects of a dominant follicle on ovarian follicular dynamics during the oestrous cycle in heifers. J. Reprod. Fertil. 91:511-519.

Kulick, L. J., D. R. Bergfelt, K. Kot, and O. J. Ginther. 2001. Follicle selection in cattle: follicle deviation and codominance within sequential waves. Biol. Reprod. 65:839-846.

Kulick, L. J., K. Kot, M. C. Wiltbank, and O. J. Ginther. 1999. Follicular and hormonal dynamics during the first follicular waves in heifers. Theriogenology 52:913-921.

Lamming, G. E., and A. O. Darwash. 1998. The use of milk progesterone profiles to characterise components of subfertility in milked dairy cows. Anim. Reprod. Sci. 52:175-190.

Lee, C. N., D. L. Cook, J. R. Parfet, C. A. Smith, R. S. Youngquist, and H. A. Garverick. 1988. Induction of persistent ovarian follicular structures following administration of progesterone near the onset of estrus in dairy cattle. J. Dairy Sci. 71:3505-3508.

Littell, R. C., G. A. Miliken, W. W. Stroup, and R. D. Wolfinger. 1996. SAS System for Mixed Models. SAS Institute Inc., Cary, NC.

López-Gatius, F., P. Santolaria, J. Yániz, M. Fenech, and M. LópezBéjar. 2002. Risk factors for postpartum ovarian cysts and their spontaneous recovery or persistence in lactating dairy cows. Theriogenology 58:1623-1632.

Mann, G. E., G. E. Lamming, and M. D. Fray. 1995. Plasma oestradiol and progesterone during early pregnancy in the cow and the effects of treatment with buserelin. Anim. Reprod. Sci. 37:121-131.

Mann, G. E., G. E. Lamming, R. S. Robinson, and D. C. Wathes. 1998 The regulation of interferon- $\tau$ production and uterine hormone receptors during early pregnancy. J. Reprod. Fertil. 54(Suppl.):317-328. 
Mihm, M., A. Baguisi, M. P. Boland, and J. F. Roche. 1994. Association between the duration of dominance of the ovulatory follicle and pregnancy rate in beef heifers. J. Reprod. Fertil. 102:123-130.

Moreira, F., C. Risco, M. F. A. Pires, J. D. Ambrose, M. Drost, M. DeLourenzo, and W. W. Thatcher. 2000. Effect of body condition on reproductive efficiency of lactating dairy cows receiving a timed insemination. Theriogenology 53:1305-1319.

Nakao, T., M. Moriyoshi, and T. Kawata. 1992. The effect of postpartum ovarian dysfunction and endometritis on subsequent reproductive performance in high and medium producing dairy cows. Theriogenology 37:341-348.

Nebel, R. L., S. M. Jobst, M. B. G. Dransfield, S. M. Pandolfi, and T. L. Bailey. 1997. Use of a radiofrequency data communication system, Heat Watch ${ }^{\circledR}$, to describe behavioral estrus in dairy cattle. J. Dairy Sci. 80(Suppl. 1):151. (Abstr.)

Nielen, M., Y. H. Schukken, D. T. Scholl, H. J. Wilbrink, and A. Brand. 1989. Twinning in dairy cattle: A study of risk factors and effects. Theriogenology 32:845-862.

Peter, A. T., W. T. K. Bosu, and R. J. DeDecker. 1989. Suppression of preovulatory luteinizing hormone surges in heifers after intrauterine infusions of Escherichia coli endotoxin. Am. J. Vet. Res. 50:368-373.

Pursley, J. R., J. S. Stevenson, and J. E. Minton. 1993. Ovarian follicular waves in dairy cows after administration of gonadotropin-releasing hormone at estrus. J. Dairy Sci. 76:2548-2560.

Pursley, J. R., M. C. Wiltbank, J. S. Stevenson, J. S. Ottobre, H. A. Garverick, and L. L. Anderson. 1997. Pregnancy rates per artificial insemination for cows and heifers inseminated at a synchronized ovulation or synchronized estrus. J. Dairy Sci. 80:295-300.

Quirk, S. M., G. J. Hickey, and J. E. Fortune. 1986. Growth and regression of ovarian follicles during the follicular phase of the oestrous cycle in heifers undergoing spontaneous and PGF-2 $\alpha$ induced luteolysis. J. Reprod. Fertil. 77:211-219.

Rasmussen, F. E., M. C. Wiltbank, J. O. Christensen, and R. R. Grummer. 1996. Effects of fenprostalene and estradiol-17 $\beta$ benzoate on parturition and retained placenta in dairy cows and heifers. J. Dairy Sci. 79:227-234.

Revah, I., and W. R. Butler. 1996. Prolonged dominance of follicles and reduced viability of bovine oocytes. J. Reprod. Fertil. 106:39-47.

Roberson, M. S., M. W. Wolfe, T. T. Stumpf, R. J. Kittok, and J. E. Kinder. 1989. Luteinizing hormone secretion and corpus luteum function in cows receiving two levels of progesterone. Biol. Reprod. 41:997-1003.

Ronchi, B., G. Stradaioli, A. Verini Supplizi, U. Bernabucci, N. Lacetera, P. A. Accorsi, A. Nardone, and E. Seren. 2001. Influence of heat stress or feed restriction on plasma progesterone, oestradiol$17 \beta, \mathrm{LH}, \mathrm{FSH}$, prolactin and cortisol in Holstein heifers. Livest. Prod. Sci. 68:231-241.

Roth, Z., R. Meidan, R. Braw-Tal, and D. Wolfenson. 2000. Immediate and delayed effects of heat stress on follicular development and its association with plasma FSH and inhibin concentration in cows. J. Reprod. Fertil. 120:83-90.

Royal, M. D., A. O. Darwash, A. P. F. Flint, R. Webb, J. A. Woolliams, and G. E. Lamming. 2000. Declining fertility in dairy cattle: Changes in traditional and endocrine parameters of fertility. Anim. Sci. 70:487-501.

Sangsritavong, S., D. K. Combs, R. Sartori, and M. C. Wiltbank. 2002. High feed intake increases blood flow and metabolism of progesterone and estradiol-17 $\beta$ in dairy cattle. J. Dairy Sci. 85:2831-2842.

Santos, J. E., J. T. Huber, C. B. Theurer, C. B. Nussio, L. G. Nussio, M. Tarazon, and D. Fish. 2000. Effects of grain processing and bovine somatotropin on metabolism and ovarian activity of dairy cows during early lactation. J. Dairy Sci. 83:1004-15.

Savio, J. D., L. Keenan, M. P. Boland, and J. F. Roche. 1988. Pattern of growth of dominant follicles during the oestrous cycle of heifers. J. Reprod. Fertil. 83:663-671.
Savio, J. D., M. P. Boland, and J. F. Roche. 1990a. Development of dominant follicles and length of ovarian cycles in post-partum dairy cows. J. Reprod. Fertil. 88:581-591.

Savio, J. D., M. P. Boland, N. Hynes, and J. F. Roche. 1990b. Resumption of follicular activity in the early postpartum period of dairy cows. J. Reprod. Fertil. 88:569-579.

Schrick, F. N., M. E. Hockett, A. M. Saxton, M. J. Lewis, H. H. Dowlen, and S. P. Oliver. 2001. Influence of subclinical mastitis during early lactation on reproductive parameters. J. Dairy Sci. 84:1407-1412.

Schemm, S. R., D. R. Deaver, L. C. Griel, Jr., and L. D. Muller. 1990. Effects of recombinant bovine somatotropin on luteinizing hormone and ovarian function in lactating dairy cows. Biol. Reprod. $42: 815-821$.

Shelton, K., M. F. Gayerie De Abreu, M. G. Hunter, T. J. Parkinson, and G. E. Lamming. 1990. Luteal inadequacy during the early luteal phase of subfertile cows. J. Reprod. Fertil. 90:1-10.

Silvia, W. J., T. B. Hatler, A. M. Nugent, and L. F. Laranja da Fonseca. 2002. Ovarian follicular cysts in dairy cows: an abnormality in folliculogenesis. Domest. Anim. Endocrinol. 23:167-177.

Sirois, J., and J. E. Fortune. 1988. Ovarian follicular dynamics during the estrous cycle in heifers monitored by real-time ultrasonography. Biol. Reprod. 39:308-317.

Sirois, J., and J. E. Fortune. 1990. Lengthening the bovine estrous cycle with low levels of exogenous progesterone: A model for studying ovarian follicular dominance. Endocrinology 127:916-925.

Spalding, R. W., R. W. Everett, and R. H. Foote. 1975. Fertility in New York artificially inseminated Holstein herds in Dairy herd improvement. J. Dairy Sci. 58:718-723.

Taylor, C., and R. Rajamahendran. 1991. Follicular dynamics, corpus luteum growth and regression in lactating dairy cattle. Can. J. Anim. Sci. 71:61-68.

Townson, D. H., P. C. W. Tsang, W. R. Butler, M. Frajblat, L. C. Griel, Jr., C. J. Johnson, R. A. Milvae, G. M. Niksic, and J. L. Pate. 2002. Relationship of fertility to ovarian follicular waves before breeding in dairy cows. J. Anim. Sci. 80:1053-1058.

Trout, J. P., L. R. McDowell, and P. J. Hansen. 1998. Characteristics of the estrous cycle and antioxidant status of lactating Holstein cows exposed to heat stress. J. Dairy Sci. 81:1244-1250.

Vasconcelos, J. L. M., R. Sartori, H. N. Oliveira, J. G. Guenther, and M. C. Wiltbank. 2001. Reduction in size of the ovulatory follicle reduces subsequent luteal size and pregnancy rate. Theriogenology 56: 307-314.

Verbeke, G., and G. Molenberghs. 1997. Linear Mixed Models in Practice: A SAS-Oriented Approach. Springer, New York, NY.

Walker, W. L., R. L. Nebel, and M. L. McGilliard. 1996. Time to ovulation relative to mounting activity in dairy cattle. J. Dairy Sci. 79:1555-1561.

Washburn, S. P., W. J. Silvia, C. H. Brown, B. T. McDaniel, and A. J. McAllister. 2002. Trends in reproductive performance in southeastern Holstein and Jersey DHI herds. J. Dairy Sci. 85:244-251.

Wilson, S. J., C. J. Kirby, A. T. Koenigsfeld, D. H. Keisler, and M. C. Lucy. 1998a. Effects of controlled heat stress on ovarian function of dairy cattle. 2. heifers. J. Dairy Sci. 81:2132-2138.

Wilson, S. J., R. S. Marion, J. N. Spain, D. E. Spiers, D. H. Keisler, and M. C. Lucy. 1998b. Effects of controlled heat stress on ovarian function of dairy cattle. 1. lactating cows. J. Dairy Sci. 81:21242131.

Wiltbank, M. C., A. Gmen, and R. Sartori. 2002. Physiological classification of anovulatory conditions in cattle. Theriogenology 57:2153.

Wiltbank, M. C., P. M. Fricke, S. Sangritasvong, R. Sartori, and O. J. Ginther. 2000. Mechanisms that prevent and produce double ovulations in dairy cattle J. Dairy Sci. 83:2998-3007.

Zar, J. H. 1996. Biostatistical Analysis. 3rd ed. Prentice-Hall, Upper Saddle River, NJ. 